\title{
Structure and Reactivity Relationships in Methyl and Hydrido Complexes of Platinum(II) by Group 15 Donor Atom Ligands
}

\author{
Stefanus Otto, ${ }^{1,2, *}$ Ebrahiem Botha, ${ }^{1}$ Andreas Roodt ${ }^{1, \#}$
}

\author{
Department of Chemistry, University of the Free State, P.O. Box 339, Bloemfontein, 9300, South Africa \\ 2 Sasol Technology Research \& Development, 1 Klasie Havenga Road, Sasolburg, 1947, South Africa \\ * Corresponding author's e-mail address: fanie.otto@sasol.com \\ \# Corresponding author's e-mail address: roodta@ufs.ac.za
}

RECEIVED: April 15, 2018 * REVISED: June 26, 2018 * ACCEPTED: June 26, 2018

THIS PAPER IS DEDICATED TO DR. BISERKA KOJIĆ-PRODIĆ ON THE OCCASION OF HER 80"Th BIRTHDAY

\begin{abstract}
Square-planar substitution reactions (chlorido for iodide, trans to methyl and hydrido as non-labile ligands) was kinetically investigated in chloroform solution in a series of platinum(II) trans-[PtRCI(L)2] complexes $\left(\mathrm{R}=\mathrm{Me}: \mathrm{L}=\mathrm{PPh}_{3}, 1 ; \mathrm{PPh}_{2} \mathrm{Fc}, 2 ; \mathrm{P}\left(\mathrm{NMe}_{2}\right)_{3}, 3 ; \mathrm{AsPh} 3,5 ; \mathrm{As}(4-\mathrm{Me}-\mathrm{Ph})_{3}\right.$, $\left.6 ; \mathrm{R}=\mathrm{H}: \mathrm{L}=\mathrm{PPh}_{3}, 7\right)$ and cis-[PtMeCl$\left.\left(\mathrm{Ph}_{2} \mathrm{PFCPPh}_{2}\right)\right]$, 4. The reactions follow the normal associative mode of activation, but with equilibria present in all steps, with rate constants for the direct substitution pathway, $k_{12}$, of $(9.1 \pm 1.0) \times 10^{-4}, 0,(1.389 \pm 0.016) \times 10^{-2},(1.51 \pm 0.15),(2 \pm 4) \times 10^{-3}$, $(2.79 \pm 0.04) \times 10^{-2}$ and $0 \mathrm{~mol}^{-1} \mathrm{dm}^{3} \mathrm{~s}^{-1}$ at $298 \mathrm{~K}$ for 1 to 7 respectively. The corresponding second order rate constants for the solvent assisted pathway, $k_{13}$, were also determined. The activation parameters for the direct and solvent assisted pathways for 3 were determined as $\Delta H^{\neq}=$ $60.4 \pm 1.4$ and $53.7 \pm 0.3 \mathrm{~kJ} \mathrm{~mol}^{-1}$, and $\Delta S^{\neq}=-78 \pm 4$ and $-142 \pm 1 \mathrm{~J} \mathrm{~mol}^{-1} \mathrm{~K}^{-1}$. A significant more than four orders-of-magnitude reactivity range

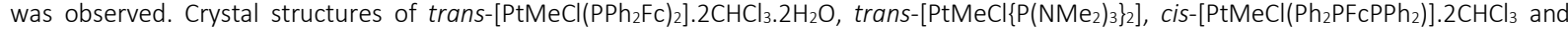
trans- $\left[\mathrm{PtHCl}\left(\mathrm{PPh}_{3}\right)_{2}\right] . \mathrm{CH}_{3} \mathrm{OH}$ are reported.
\end{abstract}

Keywords: square-planar substitution, platinum\{II\}, methyl/ hydrido complexes, associative activation, kinetics, equilibria, crystallography

\section{INTRODUCTION}

$\mathbf{S}$ QUARE-PLANAR substitution reactions in general follow an associative mode of activation almost without exception, although specific examples displaying a dissociative activation have been verified. ${ }^{[1,2]}$ Steric and electronic factors usually favour the addition of a fifth ligand to form a five-coordinate 18 electron transition state and consequently usually show a considerable extent of discrimination between different entering nucleophiles. Determining the reaction mechanisms and the rates of the reactions in a number of different compounds are still very relevant due to the extensive application in chemotherapy and catalysis. Some more recent examples of literature which includes kinetic studies, are referenced below. ${ }^{[3]}$

It has been shown that the complete behaviour, including two parallel pathways and upon inclusion of equilibrium reactions ${ }^{[4]}$ for all the separate steps, is significantly more complex, see Scheme 1.

Examples, other than substitution, involving squareplanar complexes that proceed through three coordinated transition states include the uncatalysed cis to trans isomerisation of complexes of the type cis-[PtRX $\left.\left(\mathrm{PEt}_{3}\right)_{2}\right](\mathrm{R}$ = alkyl or aryl, $\mathrm{X}=$ solvent molecule or halide ion). ${ }^{[5]}$ These complexes undergo dissociation of the solvent molecule, or halide ion, to form a 14 electron three-coordinate intermediate which rearranges to the trans isomer and then undergoes recombination with the dissociated ligand to form the four-coordinate product. Other reactions include $\beta$-hydride elimination from symmetrical and unsymmetrical dialkylbisphosphino platinum(II) complexes, ${ }^{[6]}$ insertion reactions of olefins and carbon monoxide ${ }^{[7]}$ as well as alkyl for halogen exchange reactions, ${ }^{[8]}$ for example between $\left[\mathrm{Pt}(\mathrm{Cl})_{2}\left(\mathrm{SMe}_{2}\right)_{2}\right]$ and $\left[\mathrm{Pt}(\mathrm{Me})_{2}\left(\mathrm{SMe}_{2}\right)_{2}\right]$. 


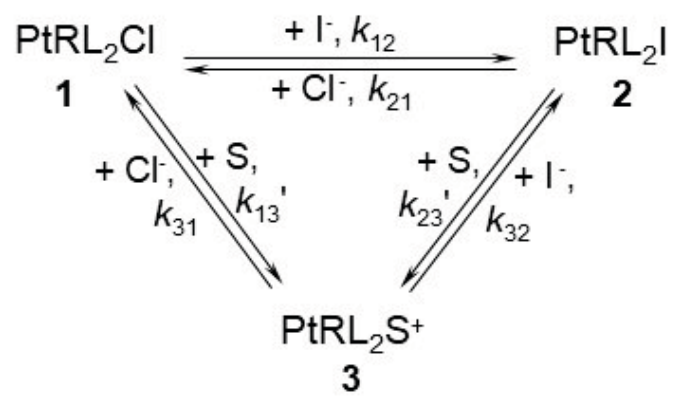

Scheme 1. Schematic presentation of a square-planar substitution reaction showing the parallel direct substitutionand solvent assisted pathways; $\left[\mathrm{PtRCIL}_{2}\right]=1,\left[\mathrm{PtRIL} \mathrm{L}_{2}\right]=2$ and $\left[\mathrm{PtRSL}_{2}\right]=3$. The subscripts of the rate constants denote the numbers of the species involved in the specific reaction, e.g. $k_{12}$ describes the rate constant for the reaction proceeding from complex 1 to 2 . The solvent (S) concentration is incorporated in the rate constants $k_{13}$ and $k_{23}$.

Basolo et al. ${ }^{\left[{ }^{[9]}\right.}$ concentrated their attempts to obtain three-coordinate intermediates by the use of bulky ancillary ligands to prevent bond formation while simultaneously enhancing dissociation due to steric crowding around the central metal atom. They compared the reaction rates of diethylenetriamine complexes with those of $\mathrm{N}$-alkyl substituted analogues according to the simple reaction given in Eq. 1:

$$
[\mathrm{M}(\mathrm{L}) \mathrm{X}]^{+}+\mathrm{Y}^{-} \longrightarrow[\mathrm{M}(\mathrm{L}) \mathrm{Y}]^{+}+\mathrm{X}^{-}
$$

$\mathrm{M}=\mathrm{Pd}(\mathrm{II})$ and $\mathrm{Pt}(\mathrm{II}), \mathrm{L}=$ diethylenetriamine and alkyl derivatives thereof.

Increased steric hindrance by alkyl functionalisation of the terminal nitrogen atoms of coordinated ethylenetriamine leads to a significant decrease in both $k_{12}$ and $k_{13}$, the nucleophile dependent and the nucleophile independent rate constants, according to the normal associative rate law as defined in Scheme 1 . In the most sterically congested systems the $k_{12}$ term becomes negligible leaving the rate of substitution dominated by the solvent assisted pathway. The kinetic behaviour of these systems resembles that found for octahedral complexes and as a result they were labelled "pseudo-octahedral" complexes. In the sterically congested aqua complexes $\left[\mathrm{M}\left(\mathrm{R}_{5} \text {-dien }\right)\left(\mathrm{H}_{2} \mathrm{O}\right)\right]^{2+}(\mathrm{R}=$ alkyl substituent, $\mathrm{M}=\mathrm{Pd}(\mathrm{II})$ and $\mathrm{Pt}(\mathrm{II}))$, the complexes regained the ability to discriminate between different entering nucleophiles while the solvent assisted pathway was kinetically undetectable. Extended studies headed mainly by van Eldik and co-workers ${ }^{[10]}$ investigated the effect of pressure on solvolysis, anation reactions and solvent exchange on these systems and showed that they still followed the conventional associative modes of activation. Methyl and hydrido complexes containing bidentate phosphine ligands spanning trans positions were also kinetically investigated, ${ }^{[11]}$ but yielded similar results.

Bond weakening of the leaving group induced by ligands exerting a strong trans influence can also promote dissociation. A study of complexes of the form trans[PtRCl( $\left.\left(\mathrm{PEt}_{3}\right)_{2}\right]\left(\mathrm{R}=\mathrm{H}, \mathrm{CH}_{3}, \mathrm{C}_{2} \mathrm{H}_{5}, \mathrm{C}_{6} \mathrm{H}_{5}\right.$, o-Tol, mesityl etc.) yielded similar results as the pseudo octahedral complexes, namely, the loss of discrimination between different entering nucleophiles as well as a dominant solvolysis pathway. ${ }^{[12]}$ The mechanism of activation was still found to be associative while in the case of the methanol solvento complexes, trans- $\left[\mathrm{Pt}(\mathrm{R})(\mathrm{MeOH})\left(\mathrm{PEt}_{3}\right)_{2}\right]^{+}, \quad$ a significant extent of nucleophile discrimination was reported, regardless of the steric size of the trans ligand R. ${ }^{[13]}$ It was shown from this study that the increase in electron density induced on the central metal atom by strong $\sigma$-donating $\mathrm{R}$ ligands markedly limited the attack of nucleophiles depending mainly on the polarizability of the donor atom (preference for the direct $\left(k_{12}\right)$ pathway) while the attack of biphilic nucleophiles (able to delocalize charge by $\pi$ interactions with the metal) is favoured.

Romeo et al. ${ }^{[1,14]}$ showed that the platinum(II) complexes cis- $\left[\mathrm{Pt}(\mathrm{R})_{2}(\mathrm{~S})_{2}\right]\left(\mathrm{R}=\mathrm{CH}_{3}{ }^{-}\right.$and $\mathrm{C}_{6} \mathrm{H}_{5}{ }^{-}, \mathrm{S}=\mathrm{Me}_{2} \mathrm{SO}$ and $\mathrm{SMe}_{2}$ ) undergo substitution of the sulphur donor ligands via a mechanism including a dissociative mode of activation. The reason stated for the sharp turnover observed in the mechanism is proposed as the presence of the strong $\sigma$-donating $\mathrm{Pt}-\mathrm{C}$ bonds which give rise to significant lengthening and weakening of the trans $\mathrm{Pt}-\mathrm{S}$ bond.

Similar results were also obtained by Elding and Wendt ${ }^{[2]}$ who showed that substitution of the phosphine ligands in cis-[ $\left[\mathrm{Pt}\left(\mathrm{SiMePh}_{2}\right)_{2}\left(\mathrm{PMe}_{2} \mathrm{Ph}\right)_{2}\right]$ by the bidentate phosphine ligand dppe (1,2-bisdiphenylphosphinoethane) follows a dissociative mode of activation. These results were confirmed by following phosphine exchange reactions by variable temperature magnetisation transfer ${ }^{1} \mathrm{H}$ NMR which showed that these reactions proceed through a mechanism in which the rate-determining step involves the breaking of the Pt-P bond. The silyl ligands are even more effective in blocking associative attack, in accordance with its higher trans influence. The authors also pointed out from the crystal and molecular structure determination that extensive distortion toward a tetrahedral conformation occurs. This was interpreted as a combination of the steric crowding experienced in the system, as well as to the high amount of electron density induced on the metal centre.

We reported previously ${ }^{[15]}$ on the kinetic behaviour of trans-[PtMeCl$\left.\left(\mathrm{SMe}_{2}\right)_{2}\right]$ towards anionic and neutral 
ligands and now extend this study to cover chlorido anation by iodide trans to a strong labilizing group in systems containing ligands with group 15 donor atoms. We thus here present results for a series of complexes trans$\left[\mathrm{PtRCl}(\mathrm{L})_{2}\right]\left(\mathrm{R}=\mathrm{Me}: \mathrm{L}=\mathrm{PPh}_{3}\right.$ 1, $\mathrm{PPh}{ }_{2} \mathrm{Fc} 2, \mathrm{P}\left(\mathrm{NMe}_{2}\right)_{3}$ 3, $\mathrm{AsPh}_{3}$ 5, $\mathrm{As}(4-\mathrm{Me}-\mathrm{Ph})_{3}$ 6; $\mathrm{R}=\mathrm{H}: \mathrm{L}=\mathrm{PPh}_{3}$ 7) and cis$\left[\mathrm{PtMeCl}\left(\mathrm{Ph}_{2} \mathrm{PFCPPh}_{2}\right)\right]$ 4. Moreover, the importance of detailed reaction mechanisms such as described here is again underlined when applied/ considered in homogeneous catalysis processes, ${ }^{[16,17]}$ or also in the in vivo activities which depend on biological reaction sequences. ${ }^{[3]}$

\section{EXPERIMENTAL}

\section{General}

All chemicals used for the preparation of the complexes were of reagent grade. The following metal complexes and ligands were available commercially: $\mathrm{K}_{2} \mathrm{PtCl}_{4}$ (Next Chimica); cis,cis-1,5-cyclooctadiene (Merck), $\mathrm{SMe}_{2}$ (Merck), MeLi (Aldrich), $\mathrm{PPh}_{3}$ (Merck), $\mathrm{AsPh}_{3}$ (Merck), $\mathrm{P}\left(\mathrm{NMe}_{2}\right)_{3}$ (Merck), As(p-Tol) ${ }_{3}$ (Strem), $\mathrm{PPh}_{2} \mathrm{FcPPh}_{2}$ (Aldrich), $\mathrm{Bu}_{4} \mathrm{NCl}$ (Merck) and $\mathrm{Bu}_{4} \mathrm{NI}$ (Merck). In the case of moisture and oxygen sensitive chemicals all reactions were performed under a nitrogen atmosphere using standard anaerobic techniques and all solvents used during the synthesis and kinetic studies were dried by standard procedures. ${ }^{[18]}$ The $\mathrm{Bu}_{4} \mathrm{NCl}$ and $\mathrm{Bu}_{4} \mathrm{Nl}$ were vacuum-dried and stored under nitrogen prior to use.

The complexes were identified using ${ }^{1} \mathrm{H},{ }^{13} \mathrm{C},{ }^{31} \mathrm{P}$ and ${ }^{195} \mathrm{Pt}$ NMR (Bruker operating at 300, 75.468, 121.497 and $64.525 \mathrm{MHz}$ respectively) as deemed necessary. The NMR spectra were recorded in $\mathrm{CDCl}_{3}$, the ${ }^{1} \mathrm{H}$ spectra were calibrated relative to the residual $\mathrm{CHCl}_{3}$ peak $(7.24 \mathrm{ppm}$ ) and the ${ }^{13} \mathrm{C}$ NMR spectra were calibrated relative to the chloroform ${ }^{13} \mathrm{C}$ resonance (77.66 ppm). From the ${ }^{13} \mathrm{C}$ NMR spectra only the chemical shift, together with the firstorder Pt-C coupling constant, of the carbon directly attached to the platinum is reported, while for the trans$\left[\mathrm{PtRI}(\mathrm{L})_{2}\right]$ complexes only the highly diagnostic methyl or hydride chemical shifts are reported from the ${ }^{1} \mathrm{H}$ spectra. The ${ }^{31} \mathrm{P}$ NMR spectra were calibrated relative to $85 \% \mathrm{H}_{3} \mathrm{PO}_{4}$ as an external standard in a capillary $(0 \mathrm{ppm})$ and the ${ }^{195} \mathrm{Pt}$ NMR spectra relative to $\mathrm{K}_{2} \mathrm{PtCl}_{4}$ as external standard (-1639 ppm).

\section{Preparation of Ligands and Complexes}

The mixture of cis- and trans- $\left[\mathrm{PtCl}_{2}\left(\mathrm{SMe}_{2}\right)_{2}\right],{ }^{[15]}$ trans[PtMeCl(SMe $\left.)_{2}\right)_{,}{ }^{[19]}[\mathrm{PtMeCl}(\mathrm{COD})],{ }^{[20]} \mathrm{Cis}-\left[\mathrm{PtCl}_{2}\left(\mathrm{PPh}_{3}\right)_{2}\right],{ }^{[21]}$ trans-[PtHCl$\left.\left(\mathrm{PPh}_{3}\right)_{2}\right]^{[22]}$ and $\mathrm{PPh}_{2} \mathrm{Fc}^{[23]}$ were prepared according to literature procedures. The solution behaviour of the respective complexes towards iodide was investigated in situ by appropriate NMR measurements. trans-[PtMeCl($\left.\left(\mathrm{PPh}_{3}\right)_{2}\right]$ 1. (a) A solution of $\mathrm{PPh}_{3}(236 \mathrm{mg}$,
$0.90 \mathrm{mmol}$ ) in acetone $(5 \mathrm{~mL})$ was added drop-wise to trans-[PtMeCl( $\left.\left.\mathrm{SMe}_{2}\right)_{2}\right](100 \mathrm{mg}, 0.27 \mathrm{mmol})$ also in acetone $(5 \mathrm{~mL})$ while vigorously stirring. The desired product precipitated shortly after all the $\mathrm{PPh}_{3}$ was added and was collected by filtration while the excess $\mathrm{PPh}_{3}$ remained in solution. Yields are virtually quantitative $213 \mathrm{mg}$ (98\%).

(b) $[\mathrm{PtMeCl}(\mathrm{COD})]$ (100 $\mathrm{mg} ; 0.28 \mathrm{mmol}$ ) was dissolved in the minimum volume of acetone $(5 \mathrm{~mL})$ and was added to $\mathrm{PPh}_{3}$ (236 mg; $0.90 \mathrm{mmol}$ ), also dissolved in acetone $(5 \mathrm{~mL})$. Slow evaporation of the solvent without stirring yields the desired product that was collected and washed with diethyl ether to remove any traces of the unreacted phosphine. Utilisation of larger amounts of the phosphine leads to the precipitation of the desired product within a few minutes in near quantitative yields. ${ }^{1} \mathrm{H} \mathrm{NMR}\left(\mathrm{CDCl}_{3}\right) \delta / \mathrm{ppm}:-0.11$ $\left(\mathrm{tt}, 3 \mathrm{H},{ }^{2} J_{\mathrm{Pt}-\mathrm{H}}=79 \mathrm{~Hz},{ }^{3} \mathrm{P}_{\mathrm{P}-\mathrm{H}}=13 \mathrm{~Hz}\right), 7.3-7.4(\mathrm{~m}, 18 \mathrm{H}), 7.6-7.8$ $(\mathrm{m}, 12 \mathrm{H}) ;{ }^{13} \mathrm{C}:-8.99$ (Me, $\left.\mathrm{tt},{ }^{1}{ }_{\mathrm{Pt}-\mathrm{C}}=655 \mathrm{~Hz}\right) ;{ }^{31} \mathrm{P} \mathrm{NMR}\left(\mathrm{CDCl}_{3}\right)$ $\delta / p p m: 29.87\left(\mathrm{t},{ }^{1} J_{\mathrm{Pt}-\mathrm{P}}=3145 \mathrm{~Hz}\right) ;{ }^{195} \mathrm{Pt} \mathrm{NMR}\left(\mathrm{CDCl}_{3}\right) \delta / \mathrm{ppm}$ : $-4646\left(t, 1_{\text {pt-p }}=3130 \mathrm{~Hz}\right)$. Anal. Calcd. mass fractions of elements, $w / \%$ for $\mathrm{C}_{37} \mathrm{H}_{33} \mathrm{ClP}_{2} \mathrm{Pt}\left(\mathrm{M}_{\mathrm{r}}=770.144\right)$ are: $\mathrm{C} 57.70$, H 4.32; Found: C 57.32, H 4.54 .

trans-[PtIMe $\left.\left(\mathrm{PPh}_{3}\right)_{2}\right] \mathbf{1 b}$. Bu $4 \mathrm{NI}(48 \mathrm{mg} ; 0.13 \mathrm{mmol})$ was added to a solution of trans-[PtMeCl( $\left.\left.\mathrm{PPh}_{3}\right)_{2}\right](10 \mathrm{mg} ; 0.013$ $\mathrm{mmol})$ in $\mathrm{CDCl}_{3}\left(3 \mathrm{~cm}^{3}\right)$ in an NMR tube $(10 \mathrm{~mm})$. The reaction progress was monitored with ${ }^{31} \mathrm{P}$ NMR confirming the quantitative conversion of the chloro to the iodo complex. ${ }^{1} \mathrm{H} \mathrm{NMR}\left(\mathrm{CDCl}_{3}\right) \delta / \mathrm{ppm}: 0.04\left(\mathrm{Me}, \mathrm{tt}, 3 \mathrm{H},{ }^{2} J_{\mathrm{pt}-\mathrm{H}}=\right.$ $\left.70 \mathrm{~Hz},{ }^{3} \mathrm{JP}_{\mathrm{P}-\mathrm{H}}=13 \mathrm{~Hz}\right) ;{ }^{31} \mathrm{P}$ NMR $\left(\mathrm{CDCl}_{3}\right) \delta / \mathrm{ppm}: 28.38\left(\mathrm{t},{ }^{1} j_{\mathrm{Pt}-\mathrm{P}}\right.$ $=3075 \mathrm{~Hz}$ ).

The same general procedures were used as described for the $\mathrm{PPh}_{3}$ derivative to also prepare the following complexes.

trans-[PtMeCl( $\left.\left(\mathrm{PPh}_{2} \mathrm{Fc}\right)_{2}\right]$ 2. Recrystallisation from a chloroform/ methanol (70/30) mixture yielded crystals suitable for X-ray analysis $273 \mathrm{mg}(98 \%) .{ }^{1} \mathrm{H}$ NMR $\left(\mathrm{CDCl}_{3}\right)$ d/ppm: $-0.02\left(\mathrm{tt}, 3 \mathrm{H},{ }^{2} J_{\mathrm{Pt}-\mathrm{H}}=80 \mathrm{~Hz},{ }^{3} J_{\mathrm{P}-\mathrm{H}}=14 \mathrm{~Hz}\right), 4.33(\mathrm{~s}$, $5 \mathrm{H}), 4.42(\mathrm{t}, 2 \mathrm{H}), 4.58(\mathrm{~m}, 2 \mathrm{H}), 7.35(\mathrm{~m}, 12 \mathrm{H}), 7.65(\mathrm{~m}, 8 \mathrm{H})$; ${ }^{13} \mathrm{C} \mathrm{NMR}\left(\mathrm{CDCl}_{3}\right) \delta / \mathrm{ppm}:-10.13\left(\mathrm{Me}, \mathrm{tt},{ }^{1} \mathrm{ptt}_{\mathrm{Pt}}=664 \mathrm{~Hz}\right) ;{ }^{31} \mathrm{P}$ NMR $\left(\mathrm{CDCl}_{3}\right) \delta / \mathrm{ppm}: 20.66\left(\mathrm{t},{ }^{1} j_{\mathrm{pt}-\mathrm{p}}=3139 \mathrm{~Hz}\right) ;{ }^{195} \mathrm{Pt} \mathrm{NMR}$ $\left(\mathrm{CDCl}_{3}\right) \delta / \mathrm{ppm}:-4575\left(\mathrm{t},{ }^{1} \mathrm{Jpt}_{\mathrm{p}-\mathrm{P}}=3130 \mathrm{~Hz}\right)$. Anal. Calcd. mass fractions of elements, $w / \%$ for $\mathrm{C}_{45} \mathrm{H}_{41} \mathrm{ClFe}_{2} \mathrm{P}_{2} \mathrm{Pt}\left(\mathrm{M}_{\mathrm{r}}=\right.$ 985.98) are: C 54.82, H 4.19; Found: C, 55.33, H, 4.54.

trans-[PtIMe $\left.\left(\mathrm{PPh}_{2} \mathrm{Fc}\right)_{2}\right]$ 2b. ${ }^{1} \mathrm{H} \mathrm{NMR}\left(\mathrm{CDCl}_{3}\right) \delta / \mathrm{ppm}: 0.13$ (Me, tt, 3H, $\left.{ }^{2} \mathrm{Jt}_{\mathrm{Pt}-\mathrm{H}}=76 \mathrm{~Hz},{ }^{3} \mathrm{JP}_{\mathrm{P}-\mathrm{H}}=14 \mathrm{~Hz}\right) ;{ }^{31} \mathrm{P} \mathrm{NMR}\left(\mathrm{CDCl}_{3}\right)$ $\delta / \mathrm{ppm}: 18.86\left(\mathrm{t},{ }^{1}{ }_{\mathrm{pt}-\mathrm{p}}=3049 \mathrm{~Hz}\right)$.

trans-[PtMeCl\{P(NMe$\left.\left.)_{3}\right\}_{2}\right]$ 3. Crystals suitable for X-ray analysis were obtained directly from the acetone reaction medium $142 \mathrm{mg}$ (88\%). ${ }^{1} \mathrm{H}$ NMR $\left(\mathrm{CDCl}_{3}\right) \delta / \mathrm{ppm}$ : 0.40 (tt, $3 \mathrm{H}$, $\left.{ }^{2} J_{\mathrm{Pt}-\mathrm{H}}=84 \mathrm{~Hz}, 3 J_{\mathrm{P}-\mathrm{H}}=12.5 \mathrm{~Hz}\right), 2.79\left(\mathrm{tt}, 36 \mathrm{H},{ }^{3} J_{\mathrm{P}-\mathrm{H}}=9.7 \mathrm{~Hz}\right)$; ${ }^{13} \mathrm{C} \mathrm{NMR}\left(\mathrm{CDCl}_{3}\right) \delta / \mathrm{ppm}:-22.33\left(\mathrm{Me}, \mathrm{tt},{ }^{1} j_{\mathrm{pt}-\mathrm{C}}=705 \mathrm{~Hz}\right) ;{ }^{31} \mathrm{P}$ NMR $\left(\mathrm{CDCl}_{3}\right) \delta / \mathrm{ppm}: 109.02\left(\mathrm{t},{ }^{1} \mathrm{Jpt}_{\mathrm{pt}}=3901 \mathrm{~Hz}\right) ;{ }^{195} \mathrm{Pt} \mathrm{NMR}$ $\left(\mathrm{CDCl}_{3}\right) \delta / \mathrm{ppm}:-4277\left(\mathrm{t},{ }^{1}{ }_{\mathrm{pt}-\mathrm{p}}=3917 \mathrm{~Hz}\right)$. Anal. Calcd. mass fractions of elements, $w / \%$ for $\mathrm{C}_{13} \mathrm{H}_{39} \mathrm{ClN}_{6} \mathrm{P}_{2} \mathrm{Pt}\left(\mathrm{M}_{\mathrm{r}}=\right.$ 
571.967) are: C,27.30, H,6.87, N 14.69; Found: C 27.62, H 7.01, N 14.24.

trans-[PtIMe $\left.\left\{\mathrm{P}\left(\mathrm{NMe}_{2}\right)_{3}\right\}_{2}\right]$ 3b. ${ }^{1} \mathrm{H} \mathrm{NMR}\left(\mathrm{CDCl}_{3}\right) \delta / \mathrm{ppm}: 0.56$ $\left(\mathrm{tt}, 3 \mathrm{H},{ }^{2} \mathrm{Jtt}_{\mathrm{Pt}}=83 \mathrm{~Hz},{ }^{3} \mathrm{~J}_{\mathrm{P}-\mathrm{H}}=12.5 \mathrm{~Hz}\right) ; 2.84\left(\mathrm{t}, 36 \mathrm{H},{ }^{3} \mathrm{~J}_{\mathrm{P}-\mathrm{H}}=9.5\right.$ $\mathrm{Hz}) ;{ }^{31} \mathrm{P} \mathrm{NMR}\left(\mathrm{CDCl}_{3}\right) \delta / \mathrm{ppm}: 107.81\left(\mathrm{t},{ }^{1} j_{\mathrm{pt}-\mathrm{P}}=3826 \mathrm{~Hz}\right)$. cis-[PtMeCl( $\left.\left(\mathrm{PPh}_{2} \mathrm{FcPPh}_{2}\right)\right]$ 4. Recrystallisation from chloroform yielded crystals suitable for $\mathrm{X}$-ray analysis 219 $\mathrm{mg}(97 \%) .{ }^{1} \mathrm{H} \mathrm{NMR}\left(\mathrm{CDCl}_{3}\right) \delta / \mathrm{ppm}: 0.56\left(\mathrm{dtd}, 3 \mathrm{H},{ }^{2} \mathrm{Jt}-\mathrm{H}=57\right.$ $\mathrm{Hz}), 3.91(\mathrm{~m}, 2 \mathrm{H}), 4.22(\mathrm{~m}, 2 \mathrm{H}) ; 4.30(\mathrm{~m}, 4 \mathrm{H}), 7.3-7.4(\mathrm{~m}$, $12 \mathrm{H}), 7.70(\mathrm{~m}, 4 \mathrm{H}) 7.8-7.9(\mathrm{~m}, 4 \mathrm{H}) ;{ }^{31} \mathrm{P} \mathrm{NMR}\left(\mathrm{CDCl}_{3}\right)$ 8/ppm: $18.89\left(\mathrm{td},{ }^{1} J_{\mathrm{pt}-\mathrm{P}}=4559 \mathrm{~Hz},{ }^{2} \mathrm{Jp}_{\mathrm{p}-\mathrm{P}}=14 \mathrm{~Hz}\right), 23.72\left(\mathrm{td},{ }^{1} J_{\mathrm{pt}-\mathrm{P}}=\right.$ $1782 \mathrm{~Hz},{ }^{2} J_{\mathrm{p}-\mathrm{p}}=14 \mathrm{~Hz}$ ); ${ }^{195} \mathrm{pt} \mathrm{NMR}\left(\mathrm{CDCl}_{3}\right) \delta / \mathrm{ppm}:-4555$ (dd, $\left.{ }^{1} J_{\mathrm{pt}-\mathrm{p}}=1782 \mathrm{~Hz},{ }^{1} J_{\mathrm{pt}-\mathrm{p}}=4559 \mathrm{~Hz}\right)$. Anal. Calcd. mass fractions of elements, $w / \%$ for $\mathrm{C}_{35} \mathrm{H}_{31} \mathrm{ClFeP}_{2} \mathrm{Pt}\left(\mathrm{M}_{\mathrm{r}}=799.95\right)$ are: $\mathrm{C}$ 52.55, H 3.91; Found: C 51.97, H 3.62.

cis-[PtIMe( $\left.\left.\mathrm{PPh}_{2} \mathrm{FcPPh}_{2}\right)\right]$ 4b. ${ }^{1} \mathrm{H}$ NMR $\left(\mathrm{CDCl}_{3}\right) \delta / \mathrm{ppm}: 0.55$ (Me, dtd, 3H, $\left.{ }^{2} J_{\mathrm{pt}-\mathrm{H}}=56 \mathrm{~Hz}\right) ;{ }^{31} \mathrm{P} \mathrm{NMR}\left(\mathrm{CDCl}_{3}\right) \delta / \mathrm{ppm}: 18.55$ $\left(\mathrm{td},{ }^{1} J_{\mathrm{pt}-\mathrm{p}}=4339 \mathrm{~Hz},{ }^{2} J_{\mathrm{p}-\mathrm{p}}=15 \mathrm{~Hz}\right), 19.02\left(\mathrm{td},{ }^{1} J_{\mathrm{pt}-\mathrm{p}}=1885 \mathrm{~Hz}\right.$, $2 J_{\mathrm{P}-\mathrm{P}}=15 \mathrm{~Hz}$ ).

trans-[PtMeCl( $\left.\left(\mathrm{AsPh}_{3}\right)_{2}\right]$ 5. Yield $233 \mathrm{mg}(96 \%) .{ }^{1} \mathrm{H} \mathrm{NMR}$ $\left(\mathrm{CDCl}_{3}\right) \delta / \mathrm{ppm}: 0.07\left(\mathrm{t}, 3 \mathrm{H},{ }^{2} \mathrm{Jpt}_{\mathrm{pt}}=78 \mathrm{~Hz}\right), 7.40(\mathrm{~m}, 18 \mathrm{H})$, $7.70(\mathrm{~m}, 12 \mathrm{H}) ;{ }^{13} \mathrm{C} \mathrm{NMR}\left(\mathrm{CDCl}_{3}\right) \delta / \mathrm{ppm}:-16.85\left(\mathrm{Me}, \mathrm{t},{ }^{1} J_{\mathrm{Pt}-\mathrm{C}}\right.$ $=614 \mathrm{~Hz}) ;{ }^{195} \mathrm{Pt} \mathrm{NMR}\left(\mathrm{CDCl}_{3}\right) \delta / \mathrm{ppm}:-4608$ (s). Anal. Calcd. mass fractions of elements, $w / \%$ for $\mathrm{C}_{37} \mathrm{H}_{33} \mathrm{ClAs}_{2} \mathrm{Pt}\left(\mathrm{M}_{\mathrm{r}}=\right.$ 858.03) are: C 51.79, H 3.88; Found C 52.12, H 4.14.

trans-[PtIMe $\left.\left(\mathrm{AsPh}_{3}\right)_{2}\right]$ 5b. ${ }^{1} \mathrm{H}$ NMR $\left(\mathrm{CDCl}_{3}\right)$ d/ppm: 0.22 (Me, t, 3H, $\left.{ }^{2} J_{\mathrm{Pt}-\mathrm{H}}=75 \mathrm{~Hz}\right), 7.40(\mathrm{~m}, 18 \mathrm{H}), 7.70(\mathrm{~m}, 12 \mathrm{H})$.

trans-[PtMeCl$\left.\left\{\mathrm{As}(\boldsymbol{p}-\mathrm{Tol})_{3}\right\}_{2}\right] 6$. The use of $\mathrm{As}(p-\mathrm{Tol})_{3}$ does not result in the precipitation of $\mathbf{6}$ from acetone due to the increased solubility induced by the Me substituents on the ligand. The solvent was removed under vacuum and the residues were washed with diethyl ether to remove traces of the free ligand $242 \mathrm{mg}(91 \%) .{ }^{1} \mathrm{H} \mathrm{NMR}\left(\mathrm{CDCl}_{3}\right) \delta / \mathrm{ppm}$ : $0.04\left(\mathrm{t}, 3 \mathrm{H},{ }^{2} J_{\mathrm{pt}-\mathrm{H}}=78 \mathrm{~Hz}\right), 2.33(\mathrm{~s}, 18 \mathrm{H}), 7.16(\mathrm{~d}, 12 \mathrm{H}), 7.57$ (d, $12 \mathrm{H}) ;{ }^{13} \mathrm{C} \mathrm{NMR}\left(\mathrm{CDCl}_{3}\right) \delta / \mathrm{ppm}:-16.85\left(\mathrm{t},{ }^{1} \mathrm{JPt}_{\mathrm{Pt}}=620 \mathrm{~Hz}\right)$; ${ }^{195} \mathrm{Pt} \mathrm{NMR}\left(\mathrm{CDCl}_{3}\right) \delta / \mathrm{ppm}$ : -4611 (s). Anal. Calcd. mass fractions of elements, $w / \%$ for $\mathrm{C}_{43} \mathrm{H}_{45} \mathrm{ClAs}_{2} \mathrm{Pt}\left(\mathrm{M}_{\mathrm{r}}=942.19\right)$ are: C 54.81, H 4.81; Found C 55.32, H 5.04.

trans-[PtIMe $\left.\left\{\mathrm{As}(\boldsymbol{p} \text {-Tol })_{3}\right\}_{2}\right]$ 6b. ${ }^{1} \mathrm{H} \mathrm{NMR}\left(\mathrm{CDCl}_{3}\right) \delta / \mathrm{ppm}: 0.20$ $\left(\mathrm{Me}, \mathrm{t}, 3 \mathrm{H},{ }^{2} \mathrm{Jt}_{\mathrm{Pt}-\mathrm{H}}=76 \mathrm{~Hz}\right), 2.36(2,18 \mathrm{H}), 7.20(\mathrm{~d}, 12 \mathrm{H}), 7.60$ (d, 12H).

trans-[PtHCl($\left.\left(\mathrm{PPh}_{3}\right)_{2}\right]$ 7. Recrystallisation from benzene/methanol gave crystals suitable for $\mathrm{X}$-ray analysis. $\mathrm{IR}(\mathrm{KBr}) \tilde{\mathrm{v}}_{\max } / \mathrm{cm}^{-1}: 2232 \mathrm{~cm}^{-1} ;{ }^{1} \mathrm{H} \mathrm{NMR}\left(\mathrm{CDCl}_{3}\right)$ d/ppm: $-16.25\left(\mathrm{tt}, 1 \mathrm{H},{ }^{1} J_{\mathrm{Pt}-\mathrm{H}}=1200 \mathrm{~Hz},{ }^{2} J_{\mathrm{P}-\mathrm{H}}=27 \mathrm{~Hz}\right), 7.3-7.4(\mathrm{~m}$, 18H), 7.6-7.7 (m, 12H); ${ }^{31} \mathrm{P} \mathrm{NMR}\left(\mathrm{CDCl}_{3}\right) d / p p m: 28.97(\mathrm{t}$, $\left.{ }^{1} J_{\mathrm{Pt}-\mathrm{P}}=3009 \mathrm{~Hz}\right) ;{ }^{195} \mathrm{Pt} \mathrm{NMR}\left(\mathrm{CDCl}_{3}\right) \mathrm{d} / \mathrm{ppm}:-4858\left(\mathrm{td},{ }^{1} J_{\mathrm{Pt}-\mathrm{P}}\right.$ $=3020 \mathrm{~Hz},{ }^{1} J_{\mathrm{pt}-\mathrm{H}}=1200 \mathrm{~Hz}$ ); Anal. Calcd. mass fractions of elements, $w / \%$ for $\mathrm{C}_{36} \mathrm{H}_{31} \mathrm{ClP}_{2} \mathrm{Pt}\left(\mathrm{M}_{\mathrm{r}}=756.11\right)$ are: $\mathrm{C}, 57.19$, H 4.13; Found C 57.42, H 4.33 .

trans-[PtIH( $\left.\left(\mathrm{PPh}_{3}\right)_{2}\right]$ 7b. ${ }^{1} \mathrm{H}$ NMR $\left(\mathrm{CDCl}_{3}\right) \delta / \mathrm{ppm}:-11.83(\mathrm{tt}$, $\left.1 \mathrm{H},{ }^{1} J_{\mathrm{Pt}-\mathrm{H}}=1261 \mathrm{~Hz},{ }^{2} J_{\mathrm{P}-\mathrm{H}}=23 \mathrm{~Hz}\right) ;{ }^{31} \mathrm{P} \mathrm{NMR}\left(\mathrm{CDCl}_{3}\right) \delta / \mathrm{ppm}$ : $28.83\left(\mathrm{t},{ }^{1} J_{\mathrm{pt}-\mathrm{p}}=2937 \mathrm{~Hz}\right)$.

\section{X-ray Crystallography}

Crystals suitable for X-ray diffraction were obtained as described in the experimental section. The data collection ( $\omega$-scans at 100 or 293(2) K) was done on a Siemens SMART CCD diffractometer using Mo $\mathrm{K}_{\alpha}(0.71073 \AA$ $)$ radiation. All reflections were merged and integrated using SAINT and were corrected for Lorentz, polarization and absorption effects using SADABS. ${ }^{[24]}$ After completion of the data collection the first 50 frames were repeated to check for decay of which none was observed. The structures were solved by the heavy atom method and refined through fullmatrix least squares cycles using the SHELXL97 ${ }^{[25]}$ software package with $\Sigma\left(/ F_{0} /-/ F_{c} /\right)^{2}$ being minimised. All non-H atoms were refined with anisotropic displacement parameters while the $\mathrm{H}$ atoms were constrained to parent sites using a riding model except for the hydride in trans$\left[\mathrm{PtHCl}\left(\mathrm{PPh}_{3}\right)_{2}\right]$ and the hydrogen atoms of the $\mathrm{H}_{2} \mathrm{O}$ in the structure of $\mathbf{2}$ that was placed from the Fourier map. The graphics were done with DIAMOND. ${ }^{[26]}$ The effective cone angles of the ligands were calculated from the structural data according to the Tolman ${ }^{[27]}$ model, but by using the actual Pt-L bond distances as described before. ${ }^{[28]} \mathrm{A}$ summary of the general crystal data and refinement parameters is given in Table 1.

\section{Kinetics Measurements}

Chloroform was washed with water to remove traces of $\mathrm{HCl}$ followed by distillation from $\mathrm{CaH}_{2}$ just before use. All kinetic measurements were performed using freshly prepared $\mathrm{Pt}(\mathrm{II})$ and $\mathrm{Bu}_{4} \mathrm{NI}$ solutions. The substitution of chloride for iodide was studied in chloroform medium by observing the absorbance changes at a suitable fixed wavelength in the region $315-355 \mathrm{~nm}$ for the various complexes, as selected from pre-recorded absorbance vs. wavelength time resolved spectra using standard UV- and stopped-flow techniques. The platinum solutions contained a ten-fold excess of chloride and were mixed with at least a ten-fold excess of iodide, ensuring pseudo first-order conditions for entering and leaving ligand in all cases. Final concentrations for $\mathrm{Pt}(\mathrm{II}), \mathrm{Cl}^{-}$and $\mathrm{I}^{-}$of $0.25,2.5$ and $2.5-150 \mathrm{mmol} \mathrm{dm}^{-3}$ respectively were used in all cases. The effect of temperature was investigated with trans-[PtMeCl\{P(NMe $\left.\left.)_{3}\right\}_{2}\right]$ 3, between 10 and $40^{\circ} \mathrm{C}$.

Tables of $k_{\text {obs }} v s$. $\left[1^{-}\right]$data and wavelengths where the experiments were conducted are given in the ESI, as well as illustrations of least-squares fits to determine the observed pseudo first-order rate constants. The observed rate constants were obtained from the absorbance vs. time traces fitted to first-order exponentials ${ }^{[15]}$ using the leastsquares programmes SCIENTIST ${ }^{[29]}$ for the UV data and OLIS[30] for the stopped-flow data. Rate constants determined by stopped-flow techniques are given as the average of at least five individual runs. The observed 
Table 1. Crystallographic data and refinement parameters for 2, 3, 4 and 7

\begin{tabular}{|c|c|c|c|c|}
\hline & $2.2 \mathrm{CHCl}_{3} .2 \mathrm{H}_{2} \mathrm{O}$ & 3 & $4.2 \mathrm{CHCl}_{3}$ & 7. $\mathrm{CH}_{3} \mathrm{OH}$ \\
\hline Empirical formula & $\mathrm{C}_{47} \mathrm{H}_{47} \mathrm{O}_{2} \mathrm{Cl}_{7} \mathrm{Fe}_{2} \mathrm{P}_{2} \mathrm{Pt}$ & $\mathrm{C}_{13} \mathrm{H}_{39} \mathrm{~N}_{6} \mathrm{ClP} \mathrm{P}_{2} \mathrm{Pt}$ & $\mathrm{C}_{37} \mathrm{H}_{33} \mathrm{Cl}_{7} \mathrm{FeP}_{2} \mathrm{Pt}$ & $\mathrm{C}_{37} \mathrm{H}_{35} \mathrm{ClOP}_{2} \mathrm{Pt}$ \\
\hline Formula weight & 1260.73 & 571.98 & 1038.66 & 788.13 \\
\hline Crystal system & Monoclinic & Monoclinic & Triclinic & Triclinic \\
\hline Space group & $\mathrm{P} 2_{1} / \mathrm{c}$ & $P 2_{1} / \mathrm{n}$ & $P \overline{1}$ & $P \overline{1}$ \\
\hline$a / \AA$ & $9.543(2)$ & $7.9212(5)$ & $10.3936(3)$ & $9.4658(4)$ \\
\hline$b / \AA$ & $10.401(3)$ & $12.4976(7)$ & $10.6421(3)$ & $11.7382(5)$ \\
\hline$c / \AA$ & $24.168(6)$ & $11.1840(6)$ & $19.2387(7)$ & $16.3040(7)$ \\
\hline$\alpha /^{\circ}$ & 90 & 90 & $97.110(2)$ & $70.5670(10)$ \\
\hline$\beta /{ }^{\circ}$ & $90.356(6)$ & $99.3750(10)$ & $95.031(2)$ & $79.8040(10)$ \\
\hline$\gamma /^{\circ}$ & 90 & 90 & $113.2750(10)$ & $74.3660(10)$ \\
\hline$V / \AA^{3}$ & 2398.9(10) & $1092.38(11)$ & 1917.87(10) & $1637.53(12)$ \\
\hline$Z$ & 2 & 2 & 2 & 2 \\
\hline$T / \mathrm{K}$ & 293 & 293 & 100 & 293 \\
\hline$D_{\mathrm{c}} / \mathrm{g} \cdot \mathrm{cm}^{-3}$ & 1.745 & 1.739 & 1.799 & 1.598 \\
\hline$\mu / \mathrm{mm}^{-1}$ & 4.000 & 6.699 & 4.620 & 4.492 \\
\hline Tmax/Tmin & $0.397 / 0.237$ & $0.209 / 0.108$ & $0.451 / 0243$ & $0.524 / 0.473$ \\
\hline$F(000)$ & 1248 & 568 & 1016 & 780 \\
\hline Crystal size/ mm & $0.50 \times 0.32 \times 0.28$ & $0.60 \times 0.52 \times 0.34$ & $0.39 \times 0.29 \times 0209$ & $0.25 \times 0.13 \times 0.13$ \\
\hline$\theta$ limit/ ${ }^{\circ}$ & 2.13 to 27.88 & 3.07 to 26.73 & 1.08 to 28.44 & 5.61 to 28.30 \\
\hline \multirow[t]{3}{*}{ Index ranges } & $-11 \leq h \leq 12$ & $-9 \leq h \leq 10$ & $-13 \leq h \leq 13$ & $-12 \leq \mathrm{h} \leq 12$ \\
\hline & $-13 \leq k \leq 13$ & $-14 \leq k \leq 15$ & $-14 \leq k \leq 14$ & $-15 \leq k \leq 15$ \\
\hline & $-31 \leq \mathrm{I} \leq 31$ & $-13 \leq \mathrm{I} \leq 14$ & $-25 \leq 1 \leq 25$ & $-21 \leq \mathrm{I} \leq 21$ \\
\hline Collected reflections & 20253 & 6472 & 49641 & 18002 \\
\hline Independent reflections & 5725 & 2286 & 9563 & 7985 \\
\hline$R_{\text {int }}$ & 0.0706 & 0.0420 & 0.0448 & 0.0253 \\
\hline Observed reflections $(\mid>2(\sigma) I)$ & 4620 & 1983 & 9237 & 6836 \\
\hline Data/ restraints/ parameters. & $5725 / 0 / 295$ & 2286/0/ 122 & $9563 / 0 / 434$ & $7985 / 0 / 385$ \\
\hline GooF & 1.219 & 1.095 & 1.200 & 0.985 \\
\hline$R(|>2(\sigma)|) \quad R^{(a)}$ & 0.0571 & 0.0391 & 0.0190 & 0.0236 \\
\hline$w R^{b}$ & 0.1273 & 0.1035 & 0.0574 & 0.0486 \\
\hline$R$ (all data) $R$ & 0.0744 & 0.0439 & 0.0201 & 0.0338 \\
\hline$w R$ & 0.1320 & 0.1077 & 0.0612 & 0.0512 \\
\hline$\Delta \rho_{\max } ; \Delta \rho_{\text {min }} /$ e..$\AA^{-3}$ & $0.973 ;-1.465$ & $0.868 ;-5.005$ & $0.795 ;-1.307$ & $0.534 ;-0.785$ \\
\hline
\end{tabular}

(a) $R=\left[(\Sigma \Delta F) /\left(\Sigma F_{0}\right)\right] \quad$ (b) $W R=\Sigma\left[w\left(F_{0}^{2}-F_{c}^{2}\right)^{2}\right] / \Sigma\left[w\left(F_{0}^{2}\right)^{2}\right]^{1 / 2}$

pseudo first-order rate constants were subsequently fitted as a function of ligand concentrations using appropriate equations as described below, while the activation parameters were calculated using the Eyring equation. ${ }^{[31,32]}$

Equilibrium constants for all phosphorous containing ligands were determined using ${ }^{31} \mathrm{P}$ NMR solutions containing known quantities of the complex and $\mathrm{Bu}_{4} \mathrm{NI}$ in $\mathrm{CDCl}_{3}$ solution at $25^{\circ} \mathrm{C}$ while ${ }^{1} \mathrm{H}$ NMR was used for the arsine ligands. UV-VIS investigations were performed using either a Hitachi 150-20, GBC 916 or Cary 50 Conc spectrophotometer, while stopped-flow investigations were done on a modified Durrum 110 instrument. All apparatus were equipped with constant temperature water baths regulating the temperature within $0.2^{\circ} \mathrm{C}$.
Based on Scheme 1, the expression in Eq. 2 may be derived (see $\mathrm{ESI}$ ), for $\left[\mathrm{Cl}^{-}\right],\left[\mathrm{I}^{-}\right] \gg[\mathrm{Pt}]$ which describes the relationship between the pseudo first-order rate constant $k_{\mathrm{obs}}$, and the concentrations of the various species in solution under equilibrium conditions:

$k_{\mathrm{obs}}=k_{12}\left(\left[\mathrm{I}^{-}\right]+\frac{\left[\mathrm{Cl}^{-}\right]}{K_{\text {eq }}}\right)+\frac{\frac{k_{13}}{k_{e q}} \frac{k_{32}}{k_{31}}\left[\mathrm{Cl}^{-}\right]+k_{13} \frac{k_{32}}{k_{31}}\left[\mathrm{I}^{-}\right]}{\left[\mathrm{Cl}^{-}\right]+\frac{k_{32}}{k_{31}}\left[\mathrm{I}^{-}\right]}$

In Eq. 2, $K_{\text {eq }}$ denotes the equilibrium constant for the formation of complex 2 and is defined as the rate of the forward reactions divided by the rate of the reverse reactions, with the direct- and solvent assisted pathways in 
equilibrium, as shown in Eq. 3.

$$
K_{e q}=\frac{k_{12}}{k_{21}}=\frac{k_{13} k_{32}}{k_{23} k_{31}}
$$

In the case of a large equilibrium constant $\left(K_{\text {eq }}\right)$, it can be shown that Eq. 2 simplifies to the well-known two-term rate law (Eq. 4) in many cases encountered for squareplanar substitution reactions.

$$
k_{\mathrm{obs}}=k_{12}[\mathrm{Y}]+k_{13}
$$

In all equations $k_{13}=k_{13}{ }^{\prime}[\mathrm{S}]$ where [S] denotes the concentration of the solvent $\left(12.50 \mathrm{~mol} \mathrm{dm}^{-3}\right.$ for $\mathrm{CHCl}_{3}$ at $25^{\circ} \mathrm{C}$ ). Eq. 2 was used to fit all the kinetic results obtained during this study. Since the concentration of the leaving $\mathrm{Cl}^{-}$ features in Eq. 2 it was thus imperative that pseudo firstorder conditions in terms of $\left[\mathrm{Cl}^{-}\right]$, with respect to $[\mathrm{Pt}]$, be employed as well.

\section{RESULTS AND DISCUSSION \\ Synthesis and NMR Characterization}

Classic methods for preparation of the platinum-methyl complexes include the action of MeLi on cis- $\left[\mathrm{Pt}(\mathrm{Cl})_{2}(\mathrm{~L})_{2}\right]$ or by oxidative addition of $\mathrm{Mel}$ to $\mathrm{Pt}(0)$ complexes of the form $\mathrm{PtL}_{4}$. The complexes in this study were prepared most conveniently from trans-[PtMeCl( $\left.\left.\mathrm{SMe}_{2}\right)_{2}\right]$ or [ $\left.\mathrm{PtMeCl}(\mathrm{COD})\right]$ by substitution of the labile $\mathrm{SMe}_{2}$ or COD ligands by the appropriate $L$ ligand. The route utilising the COD complex was prefered based on the stability of [PtMeCl(COD)] over that of trans-[PtMeCl($\left.\left(\mathrm{SMe}_{2}\right)_{2}\right]$. This enables the preparation of a considerable amount of the COD starting complex in advance which can then be converted to the appropriate phosphine or arsine complex when desired. Using

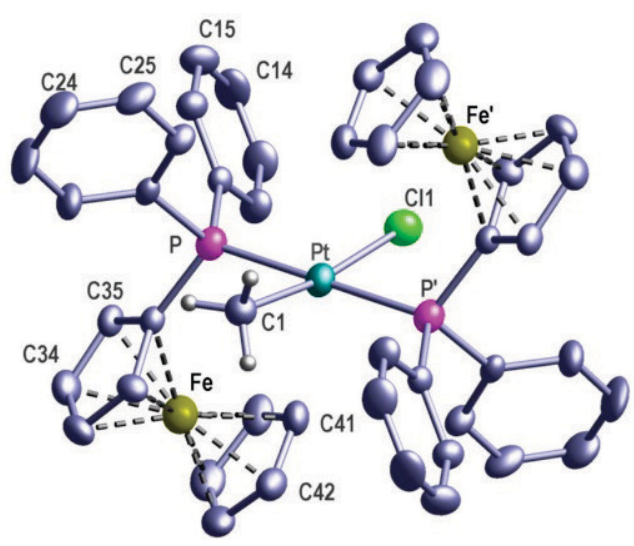

(a)
[PtMeCl(COD)] as reactant necessitates an appreciable excess of the entering ligand to ensure that monomeric complexes are formed in preference to bridging dinuclear species. [33-35] The chlorido for iodide substitution in chloroform solution was confirmed by in situ measurements of representative solutions utilising multi nuclear NMR spectroscopy; in all cases well behaved conversions were observed with no detectable side reactions. The synthesis and characterisation of trans[PtMeCl$\left.\left(\mathrm{PPh}_{3}\right)_{2}\right]$ and the substitution of $\mathrm{Cl}^{-}$by a range of halides and pseudo-halides have been described before. ${ }^{[36]}$ The methyl signal is very diagnostic and both the chemical shift and coupling to the ${ }^{195} \mathrm{Pt}$ nucleus provides a convenient probe for characterisation of the related complexes.

The first stable platinum hydrido complex, trans$\left[\mathrm{PtHCl}\left(\mathrm{PEt}_{3}\right)_{2}\right]$, was reported in $1957,{ }^{[37]}$ but may be conveniently prepared by other routes. ${ }^{[38]}$ We found the reduction of cis- $\left[\mathrm{PtCl}_{2}\left(\mathrm{PPh}_{3}\right)_{2}\right]$ with hydrazine hydrate in aqueous ethanoic solution, described by Bailar et al., ${ }^{[22]}$ to work well during our study.

All complexes were unambiguously characterised using a combination of multi-nuclear NMR, IR and X-ray crystallography ${ }^{[39]}$ and the purity of samples used for kinetic studies were confirmed by elemental analysis.

\section{Crystallography}

Selected geometrical parameters for 2, 3, 4 and $\mathbf{7}$ are presented in Table 2 while molecular diagrams with the numbering schemes and thermal displacement ellipsoids are shown in Figures 1 and 2, respectively. Since the steric and electronic factors are intricately related to the reactivity of these complexes and the accessibility by entering nucleophiles, a more detailed discussion of the

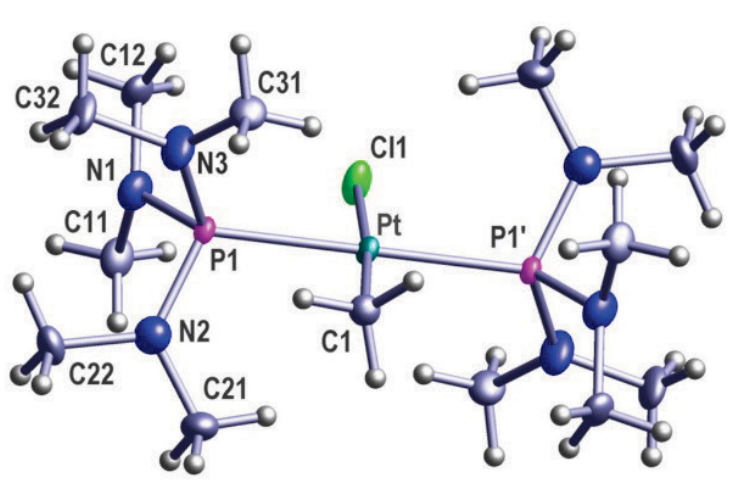

(b)

Figure 1. Molecular diagrams of 2 and 3 , showing the numbering schemes and displacement ellipsoids for (a) 2 (30\% probability) with the aromatic hydrogen atoms and the solvent molecules omitted for clarity. In the numbering scheme of the aromatic rings the first digit refers to the number of the ring (1-4) and the second to the number of the atom in the ring (1-6 for Ph and 1-5 for Cp), symmetry operator: ' = 1-x, 1-y, 1-z.; (b) 3 (50\% probability), symmetry operator: ' $=-x,-y,-z$. 
Table 2. Selected geometrical parameters for 2, 3, 4 and 7

\begin{tabular}{|c|c|c|c|c|}
\hline & 2. $\mathrm{CHCl}_{3} \cdot \mathrm{H}_{2} \mathrm{O}$ & 3 & $4.2 \mathrm{CHCl}_{3}$ & 7.MeOH \\
\hline Pt-P1 & $2.3067(17)$ & $2.3095(11)$ & $2.2269(6)$ & $2.2894(7)$ \\
\hline Pt-P2 & & & $2.3162(6)$ & $2.2899(7)$ \\
\hline $\mathrm{Pt}-\mathrm{C} 1 / \mathrm{H} 1$ & $2.20(4)$ & $2.06(2)$ & $2.130(2)$ & $1.56(3)$ \\
\hline $\mathrm{Pt}-\mathrm{Cl}$ & $2.392(11)$ & $2.468(5)$ & $2.3752(6)$ & $2.4240(7)$ \\
\hline $\mathrm{P} 1-\mathrm{C} 1 / \mathrm{N} 1$ & $1.826(7)$ & $1.697(5)$ & $1.830(3)$ & $1.828(3)$ \\
\hline $\mathrm{P} 1-\mathrm{C} 2 / \mathrm{N} 2$ & $1.833(7)$ & $1.670(4)$ & $1.825(3)$ & $1.827(3)$ \\
\hline $\mathrm{P} 1-\mathrm{C} 3 / \mathrm{N} 3$ & $1.812(8)$ & $1.659(4)$ & $1.814(2)$ & $1.823(3)$ \\
\hline $\mathrm{P} 2-\mathrm{C} 1$ & & & $1.820(3)$ & $1.825(3)$ \\
\hline $\mathrm{P} 2-\mathrm{C} 2$ & & & $1.822(3)$ & $1.826(3)$ \\
\hline P2-C3 & & & $1.797(2)$ & $1.826(3)$ \\
\hline P1-Pt-P2 & 180 & 180 & $99.28(2)$ & $174.79(2)$ \\
\hline $\mathrm{C} 1 / \mathrm{H} 1-\mathrm{Pt}-\mathrm{Cl}$ & $171.5(9)$ & $175.1(9)$ & $83.63(7)$ & $174.5(12)$ \\
\hline $\mathrm{C} 1 / \mathrm{H} 1-\mathrm{Pt}-\mathrm{P} 1$ & $\begin{array}{l}84.5(12) \\
95.5(12)\end{array}$ & $\begin{array}{l}85.9(7) \\
94.1(7)\end{array}$ & $86.61(7)$ & $85.8(12)$ \\
\hline $\mathrm{C} 1 / \mathrm{H} 1-\mathrm{Pt}-\mathrm{P} 2$ & & & $173.76(7)$ & $89.2(12)$ \\
\hline $\mathrm{Cl}-\mathrm{Pt}-\mathrm{P} 1$ & $\begin{array}{l}86.9(3) \\
93.1(3)\end{array}$ & $\begin{array}{l}89.71(13) \\
90.29(13)\end{array}$ & $170.23(2)$ & $91.17(3)$ \\
\hline $\mathrm{Cl}-\mathrm{Pt}-\mathrm{P} 2$ & & & $90.49(2)$ & $93.96(3)$ \\
\hline $\mathrm{C} 1 / \mathrm{N} 1-\mathrm{P} 1-\mathrm{Pt}$ & $119.0(2)$ & 121.44(18) & $112.37(9)$ & $116.52(9)$ \\
\hline C2/N2-P1-Pt & $109.7(2)$ & $110.40(15)$ & $112.00(8)$ & $116.38(9)$ \\
\hline C3/N3-P1-Pt & $116.2(2)$ & $112.17(15)$ & $122.18(8)$ & $111.22(9)$ \\
\hline $\mathrm{C} 1-\mathrm{P} 2-\mathrm{Pt}$ & & & 112.93(9) & $116.09(9)$ \\
\hline $\mathrm{C} 2-\mathrm{P} 2-\mathrm{Pt}$ & & & $116.81(8)$ & $115.62(9)$ \\
\hline $\mathrm{C} 3-\mathrm{P} 2-\mathrm{Pt}$ & & & 115.79(9) & $112.21(10)$ \\
\hline $\mathrm{C} 1 / \mathrm{N} 1-\mathrm{P} 1-\mathrm{C} 2 / \mathrm{N} 2$ & 103.9(3) & $101.7(2)$ & 107.39(12) & $100.02(12)$ \\
\hline $\mathrm{C} 1 / \mathrm{N} 1-\mathrm{P} 1-\mathrm{C} 3 / \mathrm{N} 3$ & $102.2(3)$ & $99.4(2)$ & $100.82(12)$ & $104.21(12)$ \\
\hline $\mathrm{C} 2 / \mathrm{N} 2-\mathrm{P} 1-\mathrm{C} 3 / \mathrm{N} 3$ & $104.2(3)$ & $110.8(2)$ & $100.49(11)$ & $107.17(13)$ \\
\hline $\mathrm{C} 1-\mathrm{P} 2-\mathrm{C} 2$ & & & $101.77(12)$ & $104.09(13)$ \\
\hline $\mathrm{C} 1-\mathrm{P} 2-\mathrm{C} 3$ & & & $105.90(12)$ & $103.86(12)$ \\
\hline $\mathrm{C} 2-\mathrm{P} 2-\mathrm{C} 3$ & & & $101.97(12)$ & $103.51(12)$ \\
\hline$\left({ }^{\theta} / 2\right)_{E 11}$ & 66.0 & 69.0 & 89.7 & 74.5 \\
\hline$\left({ }^{\theta} / 2\right)_{E 12}$ & 87.5 & 91.2 & 86.0 & 85.4 \\
\hline$\left({ }^{\theta} / 2\right)_{E 13}$ & 103.5 & 89.9 & 49.6 & 75.5 \\
\hline$\theta_{€ 1}$ & 171 & 167 & 150 & 157 \\
\hline$\left({ }^{\theta} / 2\right)_{\mathrm{E} 21}$ & & & 89.1 & 78.5 \\
\hline$\left({ }^{\theta} / 2\right)_{\mathrm{E} 22}$ & & & 57.3 & 69.6 \\
\hline$\left({ }^{\theta} / 2\right)_{\mathrm{E} 23}$ & & & 49.6 & 83.7 \\
\hline$\theta_{£ 2}$ & & & 131 & 154 \\
\hline
\end{tabular}

molecular structures is warranted and presented.

The structures of $\mathbf{2}$ and $\mathbf{3}$ show the complexes to have distorted square-planar geometries with the bulky phosphine ligands in the trans orientation as expected. Due to the symmetrical nature of the molecules both complexes crystallize on inversion centres resulting in $50 \%$ statistical disorders in the methyl and chlorido positions. In the structure of $\mathbf{2}$ the disorder renders it difficult to determine these bond lengths with a great deal of accuracy, but in $\mathbf{3}$, better accuracy was obtained and displayed an 


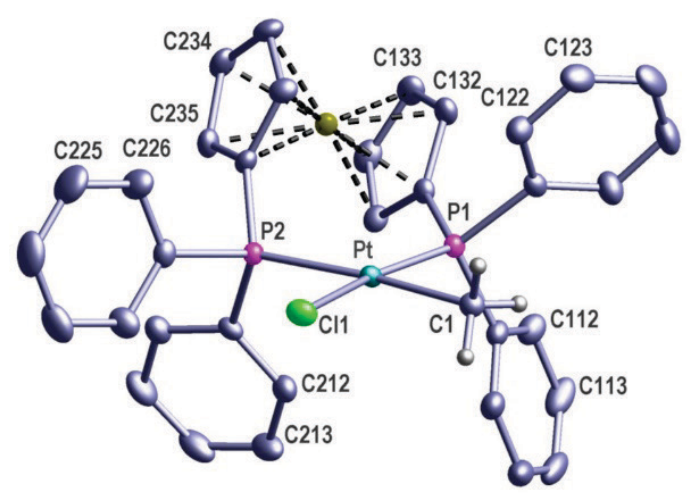

(a)

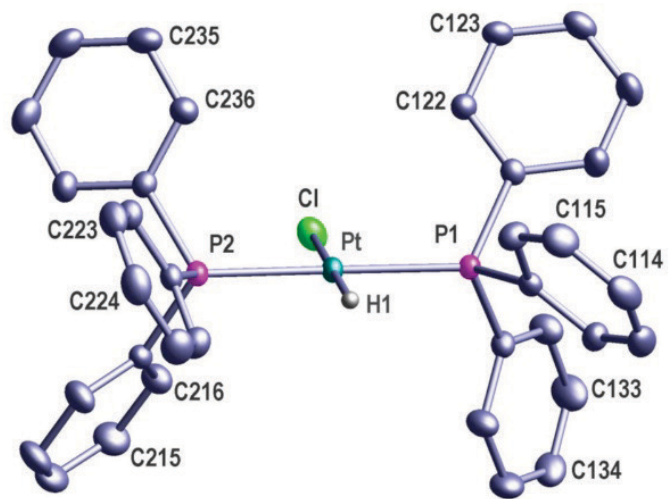

(b)

Figure 2. Molecular diagrams of $\mathbf{4}$, and $\mathbf{7}$, showing the numbering schemes and displacement ellipsoids for (a) 4 (70\% probability) with aromatic hydrogen atoms and the two chloroform solvent molecules omitted for clarity. (b) 7 (30\% probability) with the aromatic hydrogen atoms and the methanol solvent molecule omitted for clarity. For the aromatic rings the first digit refers to the number of the phosphorous (1 or 2), the second to the number of the ring (1-3) and the third to the number of the atom in the ring (1-6 for Ph and 1-5 for $\mathrm{Cp}$ ); hydrogen atoms are of arbitrary size.

exceptionally long $\mathrm{Pt}-\mathrm{Cl}$ bond distance; i.e., 2.468(5) $\AA$, represents the longest $\mathrm{Pt}-\mathrm{Cl}$ bond reported to date. ${ }^{[40]}$

Combinations of chloroform with various other solvents were employed unsuccessfully in attempts to crystallise compound $\mathbf{2}$. The addition of methanol however resulted in the rapid formation of good quality crystals. Only a single peak remained in the final electron map and was attributed to water that was introduced with the methanol which resulted in improved statistics.

This structure of $\mathbf{4}$ describes the only compound with a cis configuration investigated in the current study. Motivation for its inclusion stems from the importance of the $\mathrm{PPh}_{2} \mathrm{FcPPh}_{2}$ ligand, already recognised for its potential in various catalytic processes. ${ }^{[41]}$ It also represents a bidentate analogue of the monodentate $\mathrm{PPh}_{2} \mathrm{Fc}$ phosphine described here, enabling one to prepare complexes for kinetic investigation of cis and trans geometries containing very similar ligand systems.

The Pt(II) metal centre in $\mathbf{4}$ exhibits a significantly distorted square-planar geometry with the two $\mathrm{P}$ atoms of the bidentate ligand necessarily occupying cis positions with respect to one another. Two chloroform solvate molecules accompany each Pt moiety, exhibiting weak interactions with the chlorido ligand. The six membered chelate of the bidentate phosphine exhibits a twisted chair conformation indicative of the steric strain experienced due to the large ferrocenyl moiety. This distortion is evident from the large $P(1)-P t-P(2)$ bite angle of $99.28(2)^{\circ}$. A distinct difference is observed in the Pt-P bond distances, i.e., $\mathrm{Pt}-\mathrm{P}(2)=2.2269(6) \AA$ trans to the chlorido, versus trans to the methyl Pt-P(1) = 2.3162(6) $\AA$, respectively indicative of the stronger trans influence of the methyl compared to the chlorido ligand. The $\mathrm{Pt}-\mathrm{Cl}(1)$ bond distance of 2.3752(6) $\AA$ is within normal ranges for that expected trans to a phosphine ligand, while the $\mathrm{Pt}-\mathrm{C}(1)$ bond distance of 2.130(2) $\AA$ is slightly longer than that obtained for structures with the methyl group trans to a chlorido ligand. This elongation of the $\mathrm{Pt}-\mathrm{C}(1)$ bond is due to the larger trans influence of the phosphine ligand compared to chloride.

The structure of $\mathbf{7}$ shows a distorted square-planar geometry with angles differing slightly from the ideal $90^{\circ}$ and the bulky phosphine ligands as expected, in a trans orientation relative to one other. The contact of $3.171 \AA$ between the chlorido ligand and the oxygen of the methanol can be interpreted as a weak interaction and may also contribute to the longer $\mathrm{Pt}-\mathrm{Cl}$ bond length of 2.4240(7) $\AA$ obtained here, compared to the 2.386(4) $\AA$ from our previous study. Relatively few platinum hydrido complexes of these have been structurally characterised to date. It is generally accepted that the hydrido ligand exerts a strong trans influence due to its $\sigma$-bonding character. Extensive investigation of trans-[PtHCl $\left.\left(\mathrm{PPh}_{3}\right)_{2}\right]$ indicated several crystal polymorphs to exist as different Pt-H IR stretching frequencies were reported for solid state samples when crystallised from different solvents. ${ }^{[42]}$ Except for two preliminary studies of low accuracy, ${ }^{[43,44]}$ on different polymorphs than the one described here, no crystal structure has since been reported. ${ }^{[40]}$

In 7 the relatively larger steric demand of the chlorido ligand, as compared to the hydrido, is evident from the distorted $P(1)-P t-P(2)$ angle of $174.79(2)^{\circ}$ in the 
Table 3. Comparison of selected geometrical parameters for cis- and trans- $\left[\mathrm{PtRCl}(\mathrm{L})_{2}\right](\mathrm{R}=\mathrm{Me}$ or $\mathrm{H})$ complexes

\begin{tabular}{|c|c|c|c|c|c|}
\hline Complex & $\mathrm{Pt}-\mathrm{L}(\AA)$ & $\mathrm{Pt}-\mathrm{R}(\AA ̊)$ & $\mathrm{Pt}-\mathrm{Cl}(\AA ̊)$ & $L-P t-L\left({ }^{\circ}\right)$ & Ref. \\
\hline cis-[PtMeCl( $\left.\left(\mathrm{PPh}_{2} \mathrm{FcPPh}_{2}\right)\right]$ & $2.2269(6)$ & $2.130(2)$ & & $99.28(2)$ & Tw \\
\hline trans-[PtMeCl$\left.\left(\mathrm{PPh}_{3}\right)_{2}\right]$ & $2.2955(10)$ & $2.02(2)$ & $2.415(5)$ & 180 & {$[36]$} \\
\hline trans-[PtMeCl$\left.\left(\mathrm{PPh}_{3}\right)_{2}\right]$ & $2.297(3)$ & $2.08(1)$ & $2.431(3)$ & $175.7(1)$ & {$[46]$} \\
\hline trans-[PtMeCl( $\left(\mathrm{PPh}_{2} \mathrm{Fc}_{2}\right]$ & $2.3067(17)$ & $2.20(4)$ & $2.392(11)$ & 180 & Tw \\
\hline trans-[PtMeCl\{P(NMe $\left.\left.)_{3}\right\}_{2}\right]$ & $2.3095(11)$ & $2.06(2)$ & $2.468(5)$ & 180 & Tw \\
\hline trans-[PtMeCl $\left.\left(\mathrm{PPh}_{2} \mathrm{Me}\right)_{2}\right]$ & $2.292(2)$ & $2.081(6)$ & $2.412(2)$ & $178.92(7)$ & [47] \\
\hline trans-[PtMeCl$\left.\left(\mathrm{PCy}_{3}\right)_{2}\right]$ & $2.3431(8)$ & $2.179(13)$ & $2.440(4)$ & 180 & [28] \\
\hline trans- $\left[\mathrm{PtMeCl}\left(\mathrm{AsPh}_{3}\right)_{2}\right]$ & $2.3821(9)$ & $2.073(8)$ & $2.410(2)$ & $176.30(3)$ & [48] \\
\hline trans-[PtMeCl\{As $\left.\left.(p-\mathrm{Tol})_{3}\right\}_{2}\right]$ & $2.3879(10)$ & $2.111(9)$ & $2.397(3)$ & $175.66(4)$ & [49] \\
\hline trans- $\left[\mathrm{PtHCl}\left(\mathrm{PPh}_{3}\right)_{2}\right]$ & $2.2896(7)$ & $1.56(3)$ & $2.4240(7)$ & $174.79(2)$ & Tw \\
\hline trans-[PtHCl$\left.\left(\mathrm{PPh}_{2} \mathrm{Et}\right)_{2}\right]$ & $2.268(8)$ & & $2.422(9)$ & $171.2(3)$ & {$[50]$} \\
\hline trans-[PtHCl\{P(p-Tol $\left.\left.)_{3}\right\}_{2}\right]$ & $2.280(2)$ & & $2.384(3)$ & $167.18(9)$ & [51] \\
\hline trans- $\left[\mathrm{PtHCl}\left(\mathrm{PMe}_{3}\right)_{2}\right]$ & $2.280(6)$ & & $2.423(6)$ & $176.0(2)$ & [52] \\
\hline trans- $\left[\mathrm{PtHCl}\left(\mathrm{PiPr}_{3}\right)_{2}\right]$ & $2.286(1)$ & & $2.395(1)$ & $171.18(2)$ & [53] \\
\hline
\end{tabular}

tw $=$ this work

direction of the hydrido ligand. A Pt-H bond distance of 1.56(3) A was determined after placement of the $\mathrm{H}$ atom from the electron density map. This distance compares well with that reported for the closely related trans$\left[\mathrm{PtHBr}\left(\mathrm{PPh}_{3}\right)_{2}\right] .{ }^{[45]}$ The smaller steric crowding in the system, on the other hand, may contribute in some extent to the increased rate of substitution trans to the hydrido ligand (see below), which is generally encountered for these types of complexes.

The $\mathrm{P}\left(\mathrm{NMe}_{2}\right)_{3}$ and $\mathrm{PPh}_{2} \mathrm{Fc}$ ligands exhibit a much larger steric demand than $\mathrm{PPh}_{3}$ with cone angle values of 167 and $171^{\circ}$, compared to $c a .145^{\circ}$ for the latter, respectively.

In the case of the bidentate phosphine, $\mathrm{PPh}_{2} \mathrm{FCPPh}_{2}$, a value of $281^{\circ}$ seems to be in fair agreement with an estimated value of $299^{\circ}$ if the cone angles of $\mathrm{PPh}_{2} \mathrm{Fc}$ and $\mathrm{PPh}_{2} \mathrm{H}_{,}{ }^{[27]}$ of 171 and $128^{\circ}$ respectively, were to be simply added together. In calculating the cone angle $\mathrm{e}^{[27]}$ of bidentate phosphine ligands one may consider the ligand to be composed of two independent ligand 'fragments' and the cone angle for each of these can be calculated in the usual way. The half angle of the bridging substituent is the only complicating factor but was approximated by taking half the value of the bite angle. Substituting the half angles for the phenyl rings and half the bite angle into the usual equation yielded effective $\left(\theta_{\mathrm{E}}\right)$ cone angles for the two halves of the $\mathrm{PPh}_{2} \mathrm{FcPPh}_{2}$ ligand as $\theta_{\mathrm{E}(1)}=150^{\circ}$ and $\theta_{\mathrm{E}(2)}=$ $131^{\circ}$ for $P(2)$. These values resulted in an overall effective cone angle of $281^{\circ}$. This way of calculating the cone angles implies that the steric contribution of the ferrocenyl moiety is independent of its distance from the metal centre; an assumption that is considered quite legitimate in this specific case as that side of the complex is completely blocked to any entering nucleophile.

A summary of selected geometric parameters for several complexes are given in Table 3. By comparing the cis complex with the series of trans complexes it is evident that the $\mathrm{Pt}-\mathrm{C}$ bond is longer trans to $\mathrm{P}$ than to $\mathrm{Cl}$ while the $\mathrm{Pt}-\mathrm{Cl}$ bond is shorter trans to $\mathrm{P}$ than to $\mathrm{C}$. The $\mathrm{Pt}-\mathrm{P}$ bond is also comparable in length trans to $C$ and $P$, but longer than trans to $\mathrm{Cl}$. All of these observations can be accounted for in terms of the relative trans influences of the different ligands, the trans influence series being Me $>\mathrm{P}>\mathrm{As}>\mathrm{Cl}$.

All $\mathrm{Pt}-\mathrm{Cl}$ bond distances trans to the methyl or hydrido ligands were significantly elongated with distances larger than $2.4 \AA$ quite common. Two quite long bond distances of 2.440(4) and 2.468(5) $\AA$ were observed in the sterically crowded $\mathrm{PCy}_{3}$ and $\mathrm{P}\left(\mathrm{NMe}_{2}\right)_{3}$ systems, respectively. In all the other complexes in Table 3 exhibiting a trans conformation quite long $\mathrm{Pt}-\mathrm{Cl}$ bonds were observed, indicative of the overarching labilization of the $\mathrm{Pt}-\mathrm{Cl}$ bond in the ground state. The cis labilising effect of the arsine ligands seems to be slightly smaller than that of analogous phosphine ligands and might be contributing to some extent to the longer Pt-As bond lengths and thus also to the smaller steric demand. This agrees with additional reports from our group on this topic. [35,54-57] 


\section{Kinetic Studies}

General. This study aimed to investigate the substitution of the chlorido ligand in non-coordinating solvents to minimize solvent contributions as far as possible. Due to solubility considerations this limited the study to benzene, chloroform or dichloromethane. Pyridine and derivatives thereof, e.g. 4-Br-pyridine; 4-Me-pyridine and 4-dimethyl amino pyridine were evaluated as nucleophiles, but resulted in the unwanted substitution of the arsine ligands and were thus excluded. These factors restricted potential entering ligands to salts containing organic cations such as $\mathrm{Bu}_{4} \mathrm{~N}^{+}, \mathrm{PPh}_{4}{ }^{+}$and $\mathrm{AsPh}_{4}{ }^{+}$. However, salts containing $\mathrm{PPh}_{4}{ }^{+}$ and $\mathrm{AsPh}_{4}{ }^{+}$as cations exhibited large molar absorptivities in the UV region where most of the reactions were investigated and were for this reason also excluded. Stability checks with $\mathrm{Bu}_{4} \mathrm{NI}, \mathrm{Bu}_{4} \mathrm{NSCN}$ (slow decomposition) and $\mathrm{Et}_{4} \mathrm{NBr}$ (hygroscopic) in the potential solvents showed the most feasible combination to be $\mathrm{Bu}_{4} \mathrm{NI}$ in chloroform and was thus selected.

The equilibrium constants for the reactions could not be determined using standard spectrophotometric techniques since the ligand $\left(\mathrm{Bu}_{4} \mathrm{NI}\right)$ also absorbs strongly in the same region $(<340 \mathrm{~nm}$ ) where the reaction spectral changes are occurring. ${ }^{31} \mathrm{P}$ and ${ }^{1} \mathrm{H}$ NMR spectroscopy were thus used to determine the equilibrium constants in all cases. The equilibrium constants did not display a significant temperature dependence in the temperature range under investigation $\left(10-40^{\circ} \mathrm{C}\right)$ so the value obtained at $25^{\circ} \mathrm{C}$ was used throughout in fitting of the kinetic data to Eq. $2 .{ }^{1} \mathrm{H}$ and ${ }^{31} \mathrm{P}$ NMR were also used to verify that only the chlorido ligand was substituted for iodide as the firstand only reaction in all cases. Prolonged standing (a few days) of the solutions did, however, yield the unexpected substitution products trans- $\left[\mathrm{Pt}(\mathrm{I})_{2}(\mathrm{~L})_{2}\right]$ in a few cases as reported previously[35] in the specific case of trans$\left[\mathrm{Pt}(\mathrm{I})_{2}\left(\mathrm{AsPh}_{3}\right)_{2}\right]$. This was identified as a potential problem when investigating extremely slow reactions, such as encountered in the case of trans-[PtMeCl( $\left.\left(\mathrm{PPh}_{2} \mathrm{Fc}\right)_{2}\right]$. It was, however, verified that no traces of the trans-[Pt $\left.(\mathrm{I})_{2}(\mathrm{~L})_{2}\right]$ complexes were being formed by comparing ${ }^{31} \mathrm{P} N M R$ spectra of the reaction mixtures with that of the pure diiodido complexes.

Mechanistic studies. The total kinetic behaviour based on different aspects following from the overall rate law (Eq. 2] is now systematically discussed under five separate headings.

(a) Reaction profiles. Three distinct profiles, as shown in Figure 3, could be identified for the 'simple' substitution reaction in Eq. 1, but described for the overall process (Scheme 1) under equilibrium conditions as shown in Eq. 2. The $k_{\text {obs }}$ vs. $\left.{ }^{[-}\right]$data for the $\mathrm{AsPh}_{3}, \mathrm{P}\left(\mathrm{NMe}_{2}\right)_{3}$ and $\mathrm{PPh}_{2} \mathrm{Fc}$ complexes are thus first presented separately from the

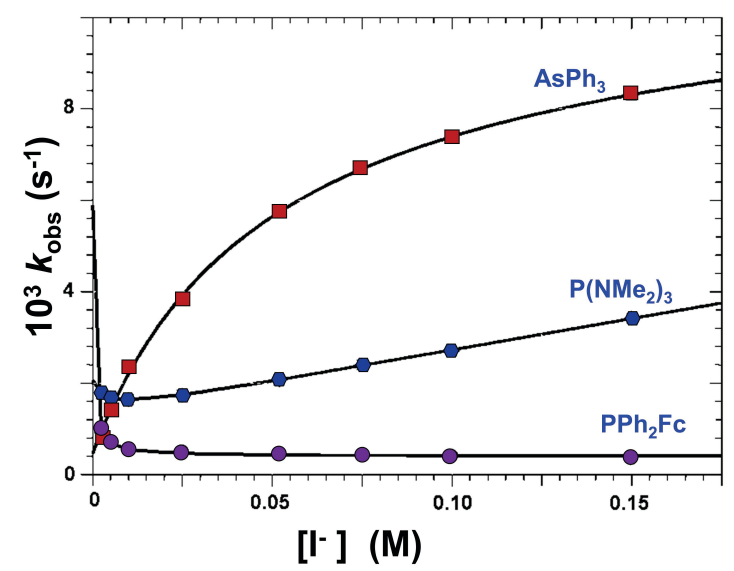

Figure 3. Illustration of the $\left.\mathrm{II}^{-}\right]$dependence of the observed pseudo first-order rate constants for selected trans$\left[\mathrm{PtMeCl}(\mathrm{L})_{2}\right]$ complexes in chloroform at $25^{\circ} \mathrm{C},[\mathrm{Pt}]=0.25$ $\mathrm{mmol} \mathrm{dm}{ }^{-3},\left[\mathrm{Cl}^{-}\right]=2.5 \mathrm{mmol} \mathrm{dm} \mathrm{m}^{-3}$.

other complexes in the group to illustrate some of the different profiles which might be obtained based on Eq. 2 . In the case of the $\mathrm{AsPh}_{3}$ complex a rate limiting relationship is obtained, indicating that the complete equation contributes to the shape of the graph, while at higher concentrations a linear dependence on $\left[^{-}\right]$may be obtained where the slope is given by $k_{12}$, as described by Eq. 3.

For the $\mathrm{P}\left(\mathrm{NMe}_{2}\right)_{3}$ complex it is evident that, except for the initial retarding effect observed, a straight line is obtained and indicating that Eq. 2 simplifies to the normal two-term rate law given in Eq. 3 at larger $\left[\mathrm{I}^{-}\right]$. The $\mathrm{PPh}_{2} \mathrm{Fc}$ complex also displays a linear dependence on [ $\left.\mathrm{I}^{-}\right]$at higher concentrations while the first decrease in the pseudo firstorder rate constant was interpreted as suppression of the solvent assisted pathway $\left(k_{13}\right)$ by the entering nucleophile. Most of the kinetic traces which were observed during this study displayed similar behaviour to that found for the $\mathrm{AsPh}_{3}$ complex.

The observations of the kinetic profiles shown in Figure 3 necessitated a complete and careful analysis of all the complexes' behaviour before any sensible comparison of relative rates could be done. Thus, all data in this study were subjected to careful analysis (Figure 4). It is consequently illustrated that Eq. 2 describes the $k_{\text {obs }} v$ s. [I-] profiles very well, which may take on completely different forms, depending on which part of the rate law dominates under the specific conditions.

For example, the $\mathrm{As}(p-\mathrm{Tol})_{3}$ complex exhibits almost a linear concentration dependence, while the plots for the $\mathrm{PPh}_{2} \mathrm{FcPPh}_{2}, \mathrm{PPh}_{3}$ (both $\mathrm{R}^{-}=\mathrm{Me}$ and $\mathrm{H}$ ) and $\mathrm{AsPh}_{3}$ complexes are slightly curved. In the case of the $\mathrm{P}\left(\mathrm{NMe}_{2}\right)_{3}$ complex the curve first show a slight decrease followed by 


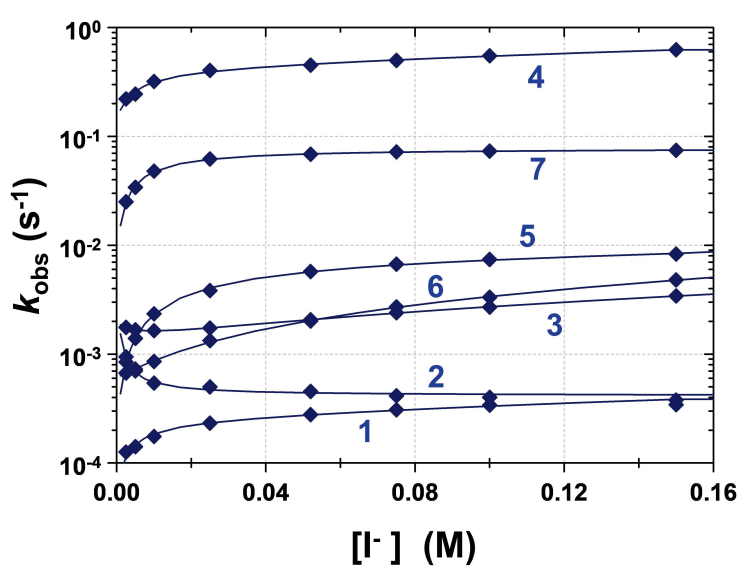

Figure 4. lodide concentration dependence of the observed pseudo first-order rate constants for cis$\left[\mathrm{PtMeCl}\left(\mathrm{PPh}_{2} \mathrm{FcPPh}_{2}\right)\right]$, the trans-[PtMeCl$\left.(\mathrm{L})_{2}\right]$ complexes and trans- $\left[\mathrm{PtHCl}\left(\mathrm{PPh}_{3}\right)_{2}\right]$ in chloroform at $25^{\circ} \mathrm{C}[\mathrm{Pt}]=0.25$ $\mathrm{mmol} \mathrm{dm}{ }^{-3},\left[\mathrm{Cl}^{-}\right]=2.5 \mathrm{mmol} \mathrm{dm}^{-3}$. Complexes trans$\left[\mathrm{PtRCI}(\mathrm{L})_{2}\right]\left(\mathrm{R}=\mathrm{Me}: \mathrm{L}=\mathrm{PPh}_{3}, 1 ; \mathrm{PPh}_{2} \mathrm{Fc}, 2 ; \mathrm{P}\left(\mathrm{NMe}_{2}\right)_{3}, 3\right.$; $\left.\mathrm{AsPh}_{3}, 5 ; \mathrm{As}(4-\mathrm{Me}-\mathrm{Ph})_{3}, 6 ; \mathrm{R}=\mathrm{H}: \mathrm{L}=\mathrm{PPh}_{3}, 7\right)$ and cis[PtMeCl $\left.\left(\mathrm{Ph}_{2} \mathrm{PFcPPh}_{2}\right)\right], 4$.

an almost linear increase, while in the case of the $\mathrm{PPh}_{2} \mathrm{Fc}$ complex a decrease is also initially observed, but then the graph levels off to form a straight line with virtually a zero slope. During the initial calculations to obtain the kinetic constants for the $\mathrm{PPh}_{2} \mathrm{Fc}$ complex a small negative value $\left[(-0.6 \pm 0.2) \times 10^{-3} \mathrm{~mol}^{-1} \mathrm{dm}^{3} \mathrm{~s}^{-1}\right]$ was obtained for $k_{12}$. This negative value was attributed to the fact that the iodide concentration could not be increased enough for the graph to reach a plateau or positive slope. Since it does not differ significantly from zero the value for $k_{12}$ was subsequently fixed at zero during the final least-squares analysis in order to obtain the other constants. Similarly, a small negative value $\left[(-0.7 \pm 0.11) \times 10^{-3} \mathrm{~mol}^{-1} \mathrm{dm}^{3} \mathrm{~s}^{-1}\right]$ was obtained for $k_{12}$ for trans-[PtHCl$\left.\left(\mathrm{PPh}_{3}\right)_{2}\right]$ and since it does not differ significantly from zero it was subsequently fixed at zero in the final least-squares analysis in order to calculate the other constants.

(b) Relative reactivities. Following a careful analysis of all the complexes' total rate profiles, a graphical comparison of the relative reactivities thereof is presented in Figure 4 while the rate constants obtained from the least-squares analyses using Eq. 2 are summarised in Table 4. The observed pseudo first-order rate constants for the reactions are plotted on a logarithmic scale to better emphasize the large differences in the reactivities of the complexes. It is clear from Figure 4 that the order of reactivity for complexes 1-7 decrease along the series trans- $\left[\mathrm{PtHCl}\left(\mathrm{PPh}_{3}\right)_{2}\right]>$ cis- $\left[\mathrm{PtMeCl}\left(\mathrm{PPh}_{2} \mathrm{FcPPh}_{2}\right)\right]>$ trans$\left[\mathrm{PtMeCl}(\mathrm{L})_{2}\right] \mathrm{L}=\mathrm{AsPh}_{3}>\mathrm{As}(p-\mathrm{Tol})_{3}>\mathrm{P}\left(\mathrm{NMe}_{2}\right)_{3}>\mathrm{PPh}_{2} \mathrm{Fc} \approx$ $\mathrm{PPh}_{3}$. Furthermore, a range of reactivity of about 4 ordersof-magnitude was observed for these complexes, but if the hydrido and cis complex is ignored only a $c a .3$ order-ofmagnitude spread is noted by interchanging phosphine and arsine ligands in the cis positions.

Figure 4 underlines the potential different behaviour of 'similar' complexes (as demonstrated in this study) and the range of profiles one may obtain once more detailed kinetic analysis is done and upon careful consideration of all contributing factors.

The cis-[PtMeCl$\left.\left(\mathrm{PPh}_{2} \mathrm{FcPPh}_{2}\right)\right]$ complex was significantly more reactive than the corresponding trans[PtMeCl( $\left(\mathrm{PPh}_{2} \mathrm{Fc}\right)_{2}$ ] complex; an observation best explained by the larger steric crowding present in the latter. It was assumed that the effective electron donating power of the $\mathrm{PPh}_{2} \mathrm{FcPPh}_{2}$ ligand would be comparable to that of two monodentate $\mathrm{PPh}_{2} \mathrm{Fc}$ ligands.

On the other hand, the $\mathrm{AsPh}_{3}$ complex was more reactive than the $\mathrm{PPh}_{3}$ analogue probably due to a combined effect of a more electrophilic metal centre and less steric crowding. Interchanging $\mathrm{AsPh}_{3}$ with the isosteric $\mathrm{As}(p-\mathrm{Tol})_{3}$ ligand results in a significant more than two order-of-magnitude suppression in the solvent assisted pathway $\left(k_{13}=0.104 \pm 0.010\right.$ vs. $0.00052 \pm 0.00004 \mathrm{~s}^{-1}$ respectively) accompanied by approximately 8-10 times

Table 4. Kinetic constants for all complexes in chloroform at $25^{\circ} \mathrm{C}$. Complexes trans- $\left[\mathrm{PtRCl}(\mathrm{L})_{2}\right]\left(\mathrm{R}=\mathrm{Me}: \mathrm{L}=\mathrm{PPh}_{3}, 1 ; \mathrm{PPh}_{2} \mathrm{Fc}, 2\right.$; $\left.\mathrm{P}\left(\mathrm{NMe}_{2}\right)_{3}, 3 ; \mathrm{AsPh}_{3}, 5 ; \mathrm{As}(4-\mathrm{Me}-\mathrm{Ph})_{3}, 6 ; \mathrm{R}=\mathrm{H}: \mathrm{L}=\mathrm{PPh}_{3}, 7\right)$ and cis-[PtMeCl$\left.\left(\mathrm{Ph}_{2} \mathrm{PFcPPh}_{2}\right)\right], 4$

\begin{tabular}{llllll}
\hline Complex & $\begin{array}{l}K_{\text {eq }} \\
\left(\mathrm{mol}^{-1} \mathrm{dm}^{3}\right)\end{array}$ & $\begin{array}{l}10^{2} k_{12} \\
\left(\mathrm{~mol}^{-1} \mathrm{dm}^{3} \mathrm{~s}^{-1}\right)\end{array}$ & $\begin{array}{l}10^{3} k_{13} \\
\left(\mathrm{~s}^{-1}\right)\end{array}$ & $\begin{array}{l}10^{4} k_{13}{ }^{\prime} \\
\left(\mathrm{mol}^{-1} \mathrm{dm}^{3} \mathrm{~s}^{-1}\right)\end{array}$ \\
\hline 1 & $1.1 \pm 0.2$ & $0.091 \pm 0.010$ & $0.254 \pm 0.012$ & $0.203 \pm 0.010$ & $0.30 \pm 0.02$ \\
2 & $0.6 \pm 0.1$ & $0^{*}$ & $0.396 \pm 0.013$ & $0.317 \pm 0.010$ & $9 \pm 5$ \\
3 & $0.5 \pm 0.1$ & $1.389 \pm 0.016$ & $1.242 \pm 0.015$ & $0.994 \pm 0.012$ & $0.80 \pm 0.02$ \\
4 & $1.5 \pm 0.3$ & $151 \pm 15$ & $408 \pm 17$ & $326 \pm 14$ & $0.43 \pm 0.04$ \\
5 & $1.2 \pm 0.3$ & $0.2 \pm 0.4$ & $10.4 \pm 1.0$ & $8.3 \pm 0.8$ & $0.052 \pm 0.006$ \\
7 & $1.0 \pm 0.2$ & $2.79 \pm 0.04$ & $0.52 \pm 0.04$ & $0.42 \pm 0.03$ & 0.0 \\
\hline
\end{tabular}

\footnotetext{
* See text
} 
enhancement of the direct pathway $\left(k_{12}=0.002 \pm 0.004\right.$ and $0.0279 \pm 0.0004 \mathrm{~mol}^{-1} \mathrm{dm}^{3} \mathrm{~s}^{-1}$ respectively). If one assumes that the equilibrium constants of $1.2 \pm 0.3$ and 1.0 \pm 0.2 for the $\mathrm{AsPh}_{3}$ and $\mathrm{As}(p-\mathrm{Tol})_{3}$ complexes do not differ significantly, then it seems that the reaction for the latter complex is more favourable compared to the $\mathrm{AsPh}_{3} \mathrm{com}$ plex by more than $c a$. one order-of-magnitude. These results are in principle contradictory to what one would expect since the $\mathrm{As}(p-\mathrm{Tol})_{3}$ ligand is considered a better electron donor than $\mathrm{AsPh}_{3}$ which should imply more electron density present on the metal centre for the former. It is also noteworthy that the $\mathrm{AsPh}_{3}$ complex reacts predominantly through the solvent assisted pathway, while the As $(p-\mathrm{Tol})_{3}$ complex seems to favour the direct substitution pathway. Some information in this regard may be found from the bond distances obtained from the crystal structures of these two complexes. The Pt-As bonds differ only slightly, but significantly, at 2.3821(9) and 2.3879(10) $\AA$ for the $\mathrm{AsPh}_{3}$ and $\mathrm{As}(p \text {-Tol })_{3}$ complexes respectively. What may be of more importance are the differences found in the $\mathrm{Pt}-\mathrm{C}$ and $\mathrm{Pt}-\mathrm{Cl}$ bond distances of 2.073(8) and 2.410(2) $\AA$ for $\mathrm{AsPh}_{3}$ and 2.111(9) and 2.397(3) $\AA$ for $A s(p-T o l)_{3}$. These values are only slightly different, but there is some indication of a loss in trans influence of the Me-group in the latter complex. This may be a result of conflicting effects on the methyl group due to the increase in electron donation from the arsine ligands. The effect in the solid state, however, is too small to firmly base an explanation on conclusions made only from it. It is however clear that the shortest $\mathrm{Pt}-\mathrm{Cl}$ bond distance corresponds to the most rapid direct substitution pathway, which is in good agreement with what one would expect from an associative mode of activation. This subtle steric effect has been well illustrated previously in iodomethane oxidative addition reactions in Vaska-type $\mathrm{Rh}(\mathrm{I})$ complexes. ${ }^{[58]}$

(c) Stability constants. The excellent correlation of the overall stability/equilibrium constants when considering the steric demand of the respective bulky ligands (from crystallography) as underlined by this study, is however noted. Considering the case where all the equilibria are shifted far to the right $\left(K_{\text {eq }} \gg 1\right)$ the complex relationship (Eq. 2) is reduced to the well-known two-term rate law in Eq. 3, often encountered for square-planar substitution reactions. The equilibrium constants of $1.5 \pm 0.3$ and $6 \pm 1$ $\mathrm{mol}^{-1} \mathrm{dm}^{3}$ obtained for cis-[PtMeCl$\left.\left(\mathrm{PPh}_{2} \mathrm{FcPPh}_{2}\right)\right]$ and trans$\left[\mathrm{PtHCl}\left(\mathrm{PPh}_{3}\right)_{2}\right]$ respectively, are the highest of the com- plexes investigated and corresponds to the sterically less crowded complexes. The two most sterically hindered complexes exhibit the smallest equilibrium constants of $0.5 \pm$ 0.1 and $0.6 \pm 0.1 \mathrm{~mol}^{-1} \mathrm{dm}^{3}$ for $\mathrm{L}=\mathrm{P}\left(\mathrm{NMe}_{2}\right)_{3}$ and $\mathrm{PPh}_{2} \mathrm{Fc}$ respectively. The equilibrium constants for the $\mathrm{L}=\mathrm{PPh}_{3}, \mathrm{AsPh}_{3}$ and $\mathrm{As}(p-\mathrm{Tol})_{3}$ complexes, which have comparable steric demands, were determined as $1.1 \pm 0.2,1.2 \pm 0.2$ and $1.0 \pm$ $0.2 \mathrm{~mol}^{-1} \mathrm{dm}^{3}$ respectively. In all cases the values for the equilibrium constants were fixed at these values during the least-squares refinement of the other constants to Eq. 2 .

(d) Discrimination factors. Another aspect of interest to note comes from considering the ratio of $k_{32} / k_{31}$; the socalled discrimination factor. ${ }^{[2,10,12-14]}$ Except for the $9 \pm 5$ obtained for trans-[PtMeCl $\left.\left(\mathrm{PPh}_{2} \mathrm{Fc}\right)_{2}\right]$, all the other values are smaller than 1 , ranging from $1.0 \pm 0.2$ to $0.052 \pm 0.006$ for trans-[PtMeCl\{As $\left.\left(p-\mathrm{Tol}_{3}\right\}_{2}\right]$ and trans-[PtMeCl$\left.\left(\mathrm{AsPh}_{3}\right)_{2}\right]$ respectively. Since this ratio gives an indication of the relative rates of the reaction of iodide $v s$. chloride on the solvento intermediate it can be seen that chloride seems to be the better entering nucleophile in most cases for the series of complexes under investigation. This discrimination is most likely an effect of the sterically congested metal centres thus favouring the smaller halogen as the preferred entering ligand. If the highest value of $9 \pm 5$, obtained for trans- $\left[\mathrm{PtMeCl}\left(\mathrm{PPh}_{2} \mathrm{Fc}\right)_{2}\right]$ is ignored, it is important to note that both the highest and lowest values for $k_{32} / k_{31}$ was obtained for complexes containing arsine ligands.

Even though the kinetic study was performed in a nonpolar, non-coordinating solvent (chloroform), some significant contributions from the solvent assisted pathway on the overall reactivity of the complexes were still observed. This, in conjunction with the fact that most of the complexes exhibit some extent of 'limiting kinetics' are indicative of especially the steric strain induced in the complexes by the bulky group 15 ligands, rendering the direct substitution path energetically unfavourable.

(e) Activation parameters. The activation parameters were determined primarily to verify that the normal associative mechanism of activation was still operative for the reactions investigated during this study. For this purpose compound 3 was selected due to the exceptional long $\mathrm{Pt}-\mathrm{Cl}$ bond distance, which made it the most likely candidate to deviate from the usual associate mechanism of activation. The values for the activation parameters reported in Table 5 were calculated using the exponential form of the Eyring

Table 5. Activation parameters for the chloride substitution by iodide in chloroform for trans- $\left[\mathrm{PtMeCl}\left\{\mathrm{P}\left(\mathrm{NMe}_{2}\right)_{3}\right\}_{2}\right] 3$

\begin{tabular}{|c|c|c|c|c|}
\hline \multirow[t]{2}{*}{ Complex } & \multicolumn{2}{|c|}{$k_{12}$} & \multicolumn{2}{|c|}{$k_{13}{ }^{\prime}$} \\
\hline & $\begin{array}{l}\Delta H^{\neq} \\
\left(\mathrm{kJ} \mathrm{mol}{ }^{-1}\right)\end{array}$ & $\begin{array}{l}\Delta S^{\neq} \\
\left(\mathrm{J} \mathrm{K}^{-1} \mathrm{~mol}^{-1}\right)\end{array}$ & $\begin{array}{c}\Delta H^{\neq} \\
\left(\mathrm{kJ} \mathrm{mol}{ }^{-1}\right)\end{array}$ & $\begin{array}{l}\Delta S^{\neq} \\
\left(\mathrm{J} \mathrm{K}^{-1} \mathrm{~mol}^{-1}\right)\end{array}$ \\
\hline trans-[PtMeCl\{P(NMe $\left.\left.)_{3}\right\}_{2}\right]$ & $58 \pm 2$ & $-85 \pm 5$ & $54.5 \pm 0.2$ & $-139 \pm 1$ \\
\hline
\end{tabular}


equation, with the Eyring plots available as ESI. The $\Delta S^{f}$ value of $k_{12}$ and $k_{13}{ }^{\prime}$, as expected for an associative mechanism of activation, range from $-85 \pm 5$ to $-139 \pm 1 \mathrm{~J}$ $\mathrm{K}^{-1} \mathrm{~mol}^{-1}$.

The activation parameters in general indicate that the usual associative mechanism of activation still holds in these complexes as large negative $\Delta S^{\neq}$values were obtained for both the direct- and solvent assisted pathways. This holds in particular for the trans[PtMeCl\{P(NMe$\left.\left.)_{3}\right\}_{2}\right]$ complex which exhibited the longest $\mathrm{Pt}-\mathrm{Cl}$ bond distance of 2.468(5) $\AA$ known to date, ${ }^{[59]}$ and showed kinetic behaviour typical of normal associative square-planar substitution.

\section{CONCLUSIONS}

A series of methyl and hydrido complexes of platinum(II) containing two group 15 donor atom ligands $P$ and $A s$ as donor atoms, was prepared and studied by X-ray crystallography and kinetically. Solid state crystal structures of four complexes trans-[PtMeCl( $\left.\left.\mathrm{PPh}_{2} \mathrm{Fc}\right)_{2}\right] \cdot 2 \mathrm{CHCl}_{3} \cdot 2 \mathrm{H}_{2} \mathrm{O}$, trans$\left[\mathrm{PtMeCl}\left\{\mathrm{P}\left(\mathrm{NMe}_{2}\right)_{3}\right\}_{2}\right]$, cis-[PtMeCl$\left.\left(\mathrm{Ph}_{2} \mathrm{PFCPPh}_{2}\right)\right] .2 \mathrm{CHCl}_{3}$ and trans- $\left[\mathrm{PtHCl}\left(\mathrm{PPh}_{3}\right)_{2}\right] \cdot \mathrm{CH}_{3} \mathrm{OH}$, were determined and the geometrical parameters obtained yielded insight regarding potential cis and trans ligand effects. The reactivities of these complexes were determined in solution in a concurrent study by extended substitution kinetic investigations of the chloride for iodide anation reactions. The reactivities spanned a four orders-of-magnitude range with cis-[PtMeCl( $\left.\left.\mathrm{Ph}_{2} \mathrm{PFCPPh}_{2}\right)\right]$ and trans-[PtHCl$\left.\left(\mathrm{PPh}_{3}\right)_{2}\right]$ being significantly more reactive than the corresponding trans- $\left[\mathrm{PtMeCl}(\mathrm{L})_{2}\right]$ complexes. All reactions follow an associative mode of activation, as usual for square planar substitution reactions, but with small equilibria present in all steps resulting in the complex and full kinetic rate law being operative, closely associated with the significant steric effects as illustrated from the structural work.

Acknowledgment. Financial support from the research fund of the University of the Free State (Materials and Nanosciences Strategic Academic Cluster), SASOL and the THRIP programme of the South African National Research Foundation is gratefully acknowledged. Part of this material is based on work supported by the South African National Research Foundation under Grant Number (GUN 2053397). Any opinion, finding and conclusions or recommendations in this material are those of the authors and do not necessarily reflect the views of the NRF.

Supplementary Information. Observed pseudo-first order rate constants for all reactions investigated and activation parameters for 3 are included separately, as well as complete raw data sets [Absorbance vs. time], with example least-squares fits for representative selected pseudo firstorder rate constants. Full crystallographic details for trans$\left[\mathrm{PtMeCl}\left(\mathrm{PPh}_{2} \mathrm{FC}_{2}\right] \cdot 2 \mathrm{CHCl}_{3} \cdot 2 \mathrm{H}_{2} \mathrm{O}\right.$, trans-[PtMeCl$\left.\left\{\mathrm{P}\left(\mathrm{NMe}_{2}\right)_{3}\right\}_{2}\right]$, cis-[PtMeCl$\left.\left(\mathrm{PPh}_{2} \mathrm{FcPPh}_{2}\right)\right] \cdot 2 \mathrm{CHCl}_{3}$ and trans-[PtHCl$\left.\left(\mathrm{PPh}_{3}\right)_{2}\right]$. $\mathrm{CH}_{3} \mathrm{OH}$ have been deposited with the Cambridge Crystallographic Data Centre, 896960 (2), 896962 (3) 896961 (4), and 896959 (7), respectively.

\section{REFERENCES}

[1] S. Lanza, D. Minnitti, R. Romeo, P. Moore, J. Sachinidis, M. L. Tobe, J. Chem. Soc. Chem. Commun. 1984, 542.

[2] O. F. Wendt, R. J. Deeth, L. I. Elding, Inorg. Chem. 2000, 39, 5271.

[3] (a) L. Maidich, A. Zucca, Guy J. Clarkson, J. P. Rourke, Organometallics 2013, 32, 3371. (b) M. Crespo, M. Martínez, S. M. Nabavizadeh, M. Rashidi, Coord. Chem. Rev. 2014, 279, 115. (c) Ž. D. Bugarčić, J. Bogojeski, B. Petrović, S. Hochreuther, R. van Eldik, Dalton Trans. 2012, 41, 12329. (d) K. Hoffmann, I. Łakomska, J. Wiśniewska, A. Kaczmarek-Kędziera, J. Wietrzyk, J. Coord. Chem. 2015, 68, 3193. (e) T. C. Johnstone, K. Suntharalingam, S. J. Lippard, Chem. Rev. 2016, 116, 3436. (f) J. Bogojeski, Ž. D. Bugarčić, R. Puchta, R. van Eldik, Eur. J. Inorg. Chem. 2010, 34, 5439. (g) S. Hochreuther, R. Puchta, R. van Eldik, Inorg. Chem. 2011, 50, 8984. (h) D. Reddy, K. J. Akerman, M. P. Akerman, D. Jaganyi, Transition Met. Chem. 2011, 36, 595. (i) S. M. Nabavizadeh, H. Amini, H. R. Shahsavari, M. Namdar, M. Rashidi, R. Kia, B. Hemmateenejad, M. Nekoeinia, A. Ariafard, F. N. Hosseini, A. Gharavi, A. Khalafi-Nezhad, M. T. Sharbati, F. Panahi, Organometallics 2011, 30, 1466. (j) S. M. Nabavizadeh, H. R. Shahsavari, M. Namdar, M. Rashidi, J. Organomet. Chem. 2011, 696, 3564.

[4] See for example: (a) J.-Y. Seguin, M. Zador, Inorg. Chim. Acta 1976, 20, 203. (b) D. J. A. de Waal, W. Robb, Inorg. Chim. Acta 1978, 26, 91. (c) L. I. Elding, A.-B. Gröning, Inorg. Chim. Acta 1980, 38, 59.

[5] (a) G. Faraone, V. Ricevuto, R. Romeo, M. Trozzi, J. Chem. Soc. A 1971, 1877. (b) S. Komiya, T. A. Albright, R. Hoffmann, J. K. Kochi, J. Am. Chem. Soc. 1976, 98, 7255. (c) R. Romeo, D. Minnitti, S. Lanza, Inorg. Chem. 1980, 19, 3663. (d) G. Alibrandi, L. Monsù Scolaro, R. Romeo, Inorg. Chem. 1991, 30, 4007. (e) A. Moravskiy, J.K. Stille, J. Am. Chem. Soc. 1981, 103, 4182. (f) R.S. Paonessa, W.C. Trogler, J. Am. Chem. Soc. 1982, 104, 3529.

[6] (a) G. M. Whitesides, J. F. Gaosh, E. R. Stedronsky, J. Am. Chem. Soc. 1972, 94, 5258. (b) G. Alibrandi, M. Cusumano, D. Minnitti, L. Monsù Scolaro, R. Romeo, Inorg. Chem. 1989, 28, 342. (c) R. Romeo, G. 
Alibrandi, L. M. Scolaro, Inorg. Chem. 1993, 32, 4688. (d) T. J. McCarthey, R. J. Nuzzo, G. M. Whitesides, J. Am. Chem. Soc. 1976, 103, 1981. (e) N. Claudhury, R. J. Puddephatt, J. Chem. Soc. Dalton Trans. 1976, 915. (f) S. Komiya, Y. Morimoto, A. Yamamoto, T. Yamamoto, Organometallics 1982, 1, 1528.

[7] (a) A. J. Deeming, B. F. G. Johnson, J. Lewis, J. Chem. Soc. Chem. Commun. 1970, 598. (b) R. W. Glyde, R. J. Mawby, Inorg. Chem. 1971, 10, 854. (c) D. L. Thorn R. Hoffmann, J. Am. Chem. Soc. 1978, 100, 2079. (d) H. C. Clark, J. Organomet. Chem. 1980, 200, 63. (e) M. Kubota, R. K. Rothrock, M. R. Kernan, B. R. Haven, Inorg. Chem. 1982, 21, 2491.

[8] J. D. Scott, R. J. Puddephatt, Organometallics, 1983, 2, 1643 .

[9] (a) W. H. Baddley, F. Basolo, J. Am. Chem. Soc. 1966, 88, 2944. (b) J. B. Goddard, F. Basolo, Inorg. Chem. 1968, 7, 936. (c) R. Roulet, H. B. Gray, Inorg. Chem 1972, 11, 2101. (d) D. A. Palmer, H. Kelm, Inorg. Chim. Acta 1975, 14, L27.

[10] (a) D. A. Palmer, R. Schmidt, R. van Eldik, H. Kelm, Inorg. Chim. Acta 1978, 29, 261. (b) D. A. Palmer H. Kelm, Aust. J. Chem. 1979, 32, 1415. (c) R. van Eldik, D. A. Palmer, R. Schmidt, H. Kelm, Inorg. Chim. Acta 1981, 50, 131. (d) L. Canovese, M. Cusumano, A. Gianetto, J. Chem. Soc. Dalton Trans. 1983, 195. (e) J. J. Pienaar, M. Kotowski, R. van Eldik, Inorg. Chem. 1989, 28, 373. (f) J. Berger, M. Kotowski, R. van Eldik, U. Frey, L. Helm, A.E. Merbach, Inorg. Chem. 1989, 28, 3759. (g) Ö. Gröning, L. I. Elding, Inorg. Chem. 1989, 28, 3366.

[11] L. I. Elding, B. Kellenberger, L. M. Venanzi, Helv. Chim. Acta 1983, 66, 1676.

[12] (a) G. Faraone, V. Ricevuto, R. Romeo, M. Trozzi, Inorg. Chem. 1969, 8, 2207. (b) G. Faraone, V. Ricevuto, R. Romeo, M. Trozzi, Inorg. Chem. 1970, 9, 1525. (c) M. Cusumano, R. Marricchi, R. Romeo, V. Ricevuto, U. Belluco, Inorg. Chim. Acta 1979, 34, 169.

[13] (a) V. Ricevuto, R. Romeo, M. Trozzi, J. Chem. Soc. Dalton Trans. 1974, 927. (b) R. Romeo, M.L. Tobe, M. Trozzi, Inorg. Chim. Acta, 1974, 11, 231.

[14] (a) S. Lanza, D. Minnitti, P. Moore, J. Sachinidis, R. Romeo, M.L. Tobe, Inorg. Chem. 1984, 23, 4428. (b) G. Alibrandi, G. Bruno, S. Lanza, D. Minnitti, R. Romeo, M. L. Tobe, Inorg. Chem. 1987, 26, 185. (c) D. Minnitti, G. Alibrandi, M. L. Tobe, R. Romeo, Inorg. Chem. 1987, 26, 3956. (d) U. Frey, L. Helm, A. E. Merbach R. Romeo, J. Am. Chem. Soc. 1989, 111, 8161. (e) G. Alibrandi, D. Minnitti, L. Monsù Scolaro, R. Romeo, Inorg. Chem. 1989, 28, 1939. (f) R. Romeo, A. Grassi L. M. Scolaro, Inorg. Chem. 1992, 31, 4383.

[15] S. Otto, A. Roodt, J. Organomet. Chem. 2006, 691, 4626.
[16] M. T. Johnson, R. Johansson, M. V. Kondrashov, G. Steyl, M. S. G. Ahlquist, A. Roodt O. F. Wendt, Organometallics, 2010, 29, 3521.

[17] H. J. van der Westhuizen, A. Roodt R. Meijboom, Polyhedron 2010, 29, 2776.

[18] D. D. Perin, W. L. F. Armarego, Purification of Laboratory Chemicals 3rd Ed. Pergamon Press.

[19] J. D. Scott, R. J. Puddephat, Organometallics 1983, 2, 1643.

[20] H. C. Clark, L.E. Manzer, J. Organomet. Chem. 1973, 59, 411.

[21] M. H. Johansson, S. Otto, Acta Cryst. 2000, C56, e12.

[22] J. C. Bailar, H. Itatani, Inorg. Chem. 1965, 4, 1618.

[23] G. P. Sollot, H. E. Mertway, S. Portnoy, J. L. Snead, J. Org. Chem. 1963, 28, 1090.

[24] Bruker, 2007, SAINT-Plus SADABS, Bruker AXS Inc., Madison, Wisconsin, USA.

[25] G. M. Sheldrick, Acta Cryst. 2008, A64, 112.

[26] K. Brandenburg, DIAMOND, Version 2.1. Crystal Impact, Bonn, Germany.

[27] C. A. Tolman, Chem. Rev. 1977, 77, 313.

[28] S. Otto, Acta Cryst. 2001, C57, 793.

[29] Scientist for Windows, Least-squares Parameter Estimation, Version 4.00.950, MicroMath, 1990.

[30] OLIS, On-Line Instrument Systems Inc., Jefferson, Ga 30549.

[31] M. R. Plutino, S. Otto, A. Roodt, L. I. Elding, Inorg. Chem. 1999, 38, 1233.

[32] A. Roodt, S. Otto, G. Steyl, Coord. Chem. Rev. 2003, $245,121$.

[33] S. Otto, J. Chem. Cryst. 2002, 31, 185.

[34] S. Otto, Inorg. Chim. Acta 2010, 363, 3316.

[35] S. Otto, A. Roodt, Acta Cryst. 1997, C53, 280.

[36] S. Otto, A. Roodt, J.G. Leipoldt, S. Afr. J. Chem. 1994, 48,114

[37] J. Chatt, L. A. Duncanson, B. L. Shaw, Proc. Chem. Soc. 1957, 343.

[38] (a) J. Chatt, B.L. Shaw, J. Chem. Soc. 1962, 5075. (b) K. Thomas, J. T. Dumler, B. W. Renoe, C. J. Nyman, D. M. Roundhill, Inorg. Chem. 1972, 11, 1795.

[39] A. Roodt, H.G. Visser, A. Brink, Crystallogr. Rev. 2011, 17, 241.

[40] F. H. Allen, Acta Cryst. 2002, B58, 380. Cambridge Structural Database, Version 1.13, 2016/17 update.

[41] See for example:(a) T. Hayashi, M. Konishi, Y. Kabor, M. Kumada, T. Higuchi K. Hirotsu, J. Am. Chem. Soc. 1984, 106, 158. (b) G. P. C. M. Dekker, C. J. Elsevier, K. Vrieze, P. W. N. M. van Leeuwen, Organometallics 1992, 11, 1598.

[42] I. Collamati, A. Furlani, G. Attioli, J. Chem. Soc. A, 1970, 1694.

[43] R. Bender, P. Braunstein, J.-M. Jud, Y. Dusausoy, Inorg. Chem. 1984, 23, 4489. 
[44] S. Otto Ph.D. Thesis, University of the Free State, 1999.

[45] A. Savaramakrishna, H. Su, J. R. Moss, Acta Cryst. 2007, E63, m244.

[46] R. Bardi, A. M. Piazzesi, Inorg. Chim. Acta 1981, 47, 249.

[47] M. A. Bennett, H. Chee, G. B. Robertson, Inorg. Chem. 1979, 18, 1061.

[48] A. Roodt, S. Otto, J. G. Leipoldt, Acta Cryst. 1995, C51, 1105.

[49] S. Otto, A. Roodt, Acta Cryst. 1996, C52, 1636.

[50] R. Eisenberg, J. A. Ibers, Inorg. Chem. 1965, 4, 773.

[51] J. A. Davies, A. A. Pinkerton, R. J. Staples, Acta Cryst. 1990, C46, 48.

[52] D. L. Packett, C. M. Jensen, R. L. Cowan, C.E. Strouse, W.C. Trogler, Inorg. Chem. 1985, 24, 3578.
[53] G. B. Robertson, P. A. Tucker, W.A. Wickramasinghe, Aust. J. Chem. 1986, 39, 1495.

[54] M. H. Johansson, S. Otto, A. Roodt, Å. Oskarsson, Acta Cryst. 2000, B56, 226.

[55] S. Otto, M.H. Johansson, Inorg. Chim. Acta. 2002, 329, 135.

[56] S. Otto, A. Roodt, Inorg. Chim. Acta. 2004, 357, 1.

[57] S. Otto, A. Roodt, Inorg. Chim. Acta. 2002, 331, 199.

[58] S. Otto, S.N. Mzamane, A. Roodt., Modern Coordination Chemistry, The Legacy of Joseph Chatt, edited by G. J. Leigh \& N. Winterton, 2002, 328.

[59] P. Kapoor, K. Lövqvist, Å. Oskarsson, Acta Cryst. 1995, C51, 611. 